\title{
Active sinking at the bottom of the Rincón de Parangueo Maar (Guanajuato, México) and its probable relation with subsidence faults at Salamanca and Celaya
}

\author{
José Jorge Aranda-Gómez ${ }^{1, *}$, Gilles Levresse ${ }^{1}$, Jesús Pacheco Martínez², \\ José Alfredo Ramos-Leal ${ }^{3}$, Gerardo Carrasco-Núñez ${ }^{1}$, Elizabeth Chacón-Baca ${ }^{4}$, \\ Gildardo González-Naranjo ${ }^{1}$, Gabriel Chávez-Cabello ${ }^{4}$, Marina Vega-González ${ }^{1}$, \\ Gabriel Origel $^{5}$, Cristina Noyola-Medrano ${ }^{3}$ \\ ${ }^{1}$ Centro de Geociencias, Universidad Nacional Autónoma de México, Campus Juriquilla, Querétaro, Qro. México. \\ ${ }^{2}$ Centro del Diseño y la Construcción, Universidad Autónoma de Aguascalientes, Av. Universidad 940, Aguascalientes, Ags., México. \\ ${ }^{3}$ División de Geociencias Aplicadas, Instituto Potosino de Investigación Científica y Tecnológica, San Luis Potosí, SLP, México. \\ ${ }^{4}$ Facultad de Ciencias de la Tierra, Universidad Autónoma de Nuevo León, Carretera a Cerro Prieto Km. 8, Linares, Nuevo León, \\ México. \\ ${ }^{5}$ AGROASEMEX S.A. \\ *jjag@servidor.unam.mx
}

\begin{abstract}
Rincon de Parangueo is a Quaternary maar that had a perennial lake until the 1980s. The lake was gradually desiccated as a consequence of drawdown in the Salamanca-Valle de Santiago regional aquifer and now functions as a playa-lake. In contrast with the features observed in other crater-lakes in the region (La Alberca, Cíntora, and San Nicolás), which also dried up at the same time, the bottom of the Rincón crater displays clear evidence of active deformation associated with mass movement of lake sediments towards the depocenter inside the crater. The most conspicuous topographic feature is a $10-12 \mathrm{~m}$ high scarp parallel to the former lake coast. The scarp is produced by an annular shaped normal fault system, down towards the depocenter. Evidence of active mass movement is observed along the topographic scarp. Rotational slides associated with rollover anticlines and local grabens produced by antithetic faults are common on the eastern and northern parts of the scarp. Planar slides with open folds at their base occur at western part of the lake basin.

Evaporites (trona, thermonatrite, eitelite, halite, and silvite) are abundant in the playa-lake sediments. Their presence makes us believe that a mass removal process is acting as a consequence of salt dissolution and infiltration of the brine towards the aquifer. This process, probably in conjunction with lake sediment compaction and/or diatreme subsidence, may explain the significantly higher fault displacement rate observed inside the crater $(\approx 50 \mathrm{~cm} /$ year $)$ in comparison with active faults elsewhere in the Salamanca-Valle de Santiago aquifer ( $\approx 6 \mathrm{~cm} /$ year $)$.
\end{abstract}

Keywords: drawdown, maar, evaporite, stromatolite, landslide.

\section{Resumen}

Rincón de Parangueo es un maar cuaternario que hasta los años ochenta contenía un lago perenne en su interior. El lago fue gradualmente desecado como consecuencia de sobre-explotación del acuifero regional Salamanca-Valle de Santiago y ahora funciona como un lago-playa. A diferencia de lo que se observa en otros lagos-cráter de la región (La Alberca, Cíntora y San Nicolás) que también fueron desecados en la misma época, en el fondo del cráter de Rincón se pueden apreciar evidencias claras de deformación 
activa relacionadas al movimiento en masa de los sedimentos lacustres hacia el depocentro en el cráter. El rasgo topográfico más conspicuo es un escarpe de $10-12 \mathrm{~m}$ de alto, cercano a la antigua linea de costa del lago, que refleja a un sistema de fallas normales escalonadas, con forma anular y bloques hundidos hacia el depocentro. En el escarpe se observan procesos de remoción en masa que incluyen principalmente deslizamientos rotacionales en la porción oriental y septentrional del escarpe y deslizamientos planares al occidente. Asociados a los movimientos rotacionales hay pliegues roll-over y fallas antitéticas que producen grábenes pequeños cerca de los planos principales de falla. Pliegues abiertos y domos se presentan al pie de los deslizamientos planares en la porción occidental del lago desecado.

La abundancia de evaporitas (trona, termonatrita, eitelita, halita y silvita) en el fondo del lago asociadas al hecho de que ahora funciona como lago-playa, nos hacen suponer que existe un proceso de remoción de masa causado por la disolución de las sales e infiltración de la salmuera hacia el acuifero. Este proceso, posiblemente asociado a compactación de los sedimentos lacustres y/o de la diatrema que posiblemente subyace al maar, puede explicar la diferencia significativa entre la tasa de desplazamiento en las fallas adentro del cráter ( $\approx 50 \mathrm{~cm} /$ año $)$ con aquellas en otros sitios del acuifero Salamanca-Valle de Santiago ( $\approx 6 \mathrm{~cm} /$ año $)$.

Palabras clave: abatimiento, maar, evaporita, estromatolito, movimiento de ladera.

\section{Purpose and scope}

Rincón de Parangueo crater-lake was gradually desiccated in the past decades. This phenomenon occurred during the 1980s as a consequence of drawdown in the Valle de Santiago - Salamanca aquifer. Land subsidence and formation of aseismic faults is commonly associated with drawdown in confined and semi-confined aquifers throughout El Bajío plain (Figure 1), which is a vast region where a large number of wells are pumping out groundwater to sustain intensive agriculture and a growing population. Land subsidence and associated faulting has been documented in Salamanca (e.g. Borja-Ortíz and Rodríguez, 2004), located $14 \mathrm{~km} \mathrm{NNW}$ of the center of the Rincón de Parangueo crater.

A large number of deformation features can be observed on the surface of the desiccated lake bed inside the crater; the most remarkable structure is a topographic scarp 10 - 12 $\mathrm{m}$ high on the average, which was produced by a segmented normal fault with an annular shape that formed around the former lake depocenter. The fault system is located near the former lake shore. It has been inferred that the annular scarp reflects the original bathymetry at the bottom of lake (e.g. Escolero-Fuentes and Alcocer-Durand, 2004) or that it was produced by the deformation and subaqueous landslides during the 8.1 magnitude earthquake of September 19, 1985 (Kienel et al., 2009). As opposed to the published interpretations about the origin of the scarp, we believe that it is the product of local accelerated subsidence which began as soon as the lake was desiccated and it is a consequence of one or several of the following factors:

- Dissolution and removal of evaporites [trona: $\mathrm{Na}_{3} \mathrm{H}\left(\mathrm{CO}_{3}\right)_{2} \cdot 2 \mathrm{H}_{2} \mathrm{O}$; halite: $\left.\mathrm{NaCl}\right]$ which are abundant in the lake sediments, and/or

- $\quad$ Progressive compaction of the lake sediments and a diatreme located below the maar crater, and/or

- Land subsidence, as it is observed in other parts of the Valle de Santiago - Salamanca aquifer.
Independent of the origin of the ring fault, as a consequence of local conditions such as the size and curvature of the ring fault and the occurrence of dry-onthe-surface and water-saturated at depth, finely laminated mudstones, the topographic scarp is the ideal place to observe and interpret the formation of rotational landslides and associated structures. Furthermore, compared with other localities in El Bajío region where "subsidence-creep-fault processes" (Ávila-Olivera and Garduño-Monroy, 2008) are occurring, displacement rate at the Rincón de Parangueo annular fault is one order of magnitude larger.

This paper is a follow-up and builds on guidebooks associated with field trips held during WRI-13 (ArandaGómez et al., 2010a) and EISOLS (Aranda-Gómez et al., 2010 b) meetings. Large portions of text were extracted from those unpublished documents. Emphasis in the WRI guidebook was centered on the fact that Rincón de Parangueo is a hydrovolcanic structure and on the origin of the extreme salinity of its water; the EISOLS fieldtrip focused on land subsidence related to drawdown in potentially multiple aquifers at El Bajío region. Six active faults produced by land subsidence in Celaya (Figure 1) have caused substantial damage to buildings, pavement, drainage and water systems, as well as to historical monuments. A fault in Salamanca (Figure 1) affects an oil refinery and has caused severe contamination of a shallow aquifer in the region. Four maar-type volcanoes around Valle de Santiago (Figure 1) have been affected by drawdown, which caused desiccation of the lakes inside the craters. La Alberca crater shows on its walls clear evidence of the desiccation process and allows a quick calculation of the drawdown rate (e.g. Escolero-Fuentes and Alcocer-Durand, 2004). The bottom of both La Alberca and Hoya San Nicolás maars display the characteristic morphology shown by these lakes after desiccation and allow a comparison with the strikingly different morphology of Rincón de Parangueo, where rapid subsidence has occurred in the past decades.

The relative age of the Rincón de Parangueo maar with 


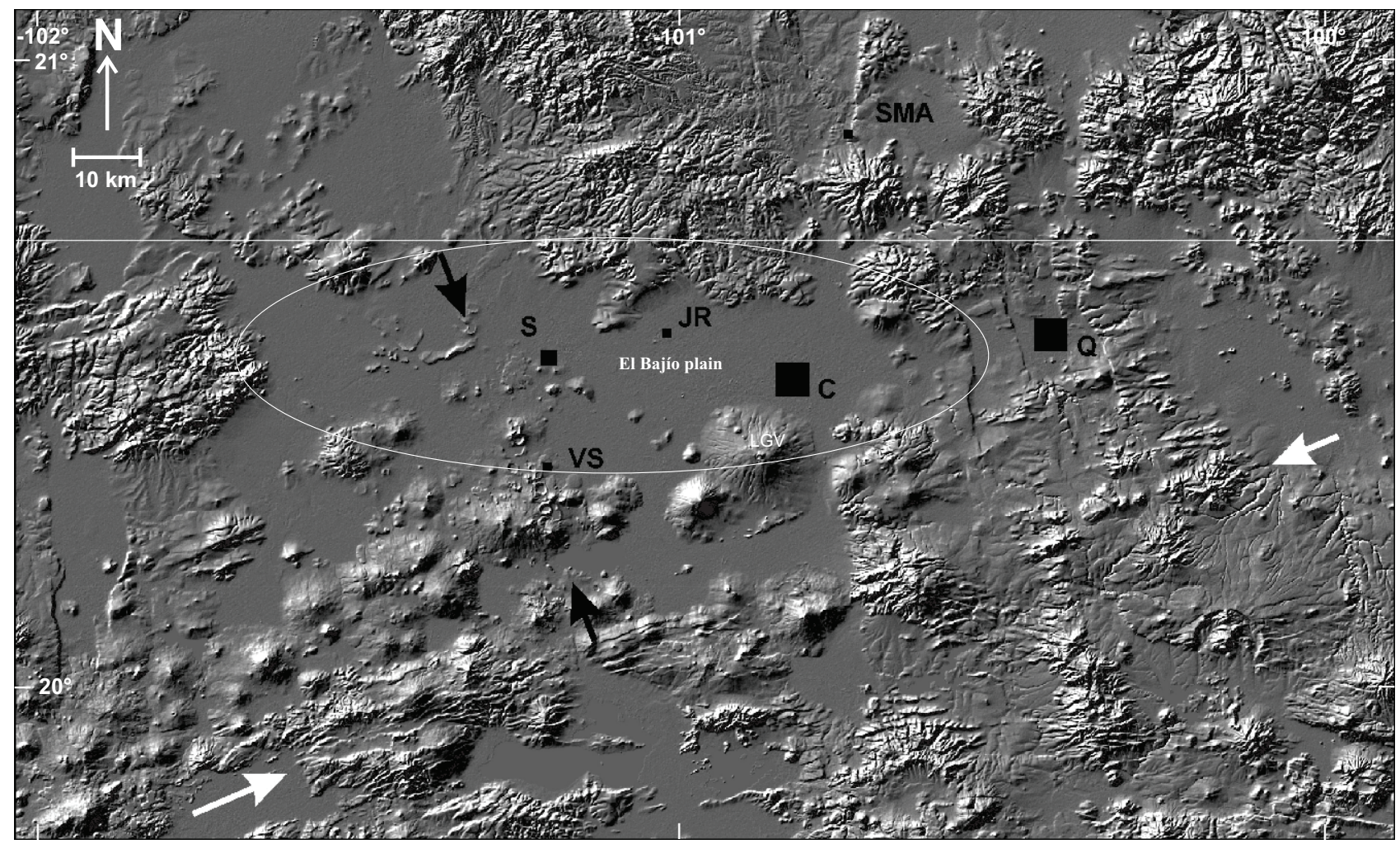

Figure 1. Shaded relief map of El Bajío region and its surroundings. Black arrows point out the maar lineament where Rincón de Parangueo is located; white arrows signal the Chapala rift fault trend. Note that faults of the Taxco - San Miguel Allende system are well exposed in the Querétaro area and are roughly parallel to subsidence-related faults both in Celaya and Querétaro. Near the SW corner of the figure is the N-S Penjamillo graben. C= Celaya, $\mathrm{S}$ $=$ Salamanca, $\mathrm{VS}=$ Valle de Santiago, $\mathrm{JR}=$ Juventino Rosas, $\mathrm{SMA}=$ San Miguel Allende, $\mathrm{Q}=$ Querétaro, and LGV $=$ La Gavia volcano

respect to other five volcanoes in the Parangueo volcanic complex is briefly discussed in the paper. A general description of the deformation features along the ring fault at the bottom of this crater, as well as discussions of: 1) the origin of the extreme alkalinity of this lake and 2) a possible mechanism of soluble salt removal from the interior of the crater and its environmental consequences are included. In addition to this, the lake inside Rincon de Parangueo sustains a reef-like colony of stromatolites, which is now partially destroyed by subsidence and associated landslide activity. Complete destruction of this habitat will occur in the near future.

\section{Introduction: phreatomagmatic activity and the Valle de Santiago volcanic field}

The phreatomagmatic volcanoes of Valle de Santiago are located at the northern end of the Michoacán-Guanajuato volcanic field (MGVF; Figure 2), a vast region $(\approx 40000$ $\mathrm{km}^{2}$ ) with more than 1000 monogenetic volcanoes in the central part of the Trans Mexican Volcanic Belt (TMVB) (Hasenaka and Carmichael, 1985). Magmatic activity at the TMVB is produced by subduction of the Rivera and Cocos oceanic plates underneath the North American plate along the Middle American Trench (Figures 2 and 3).
Chemical compositions of the volcanic products of the Valle de Santiago area suggest that an additional component is present in the genesis of some of the young volcanoes in the region. While some rocks have a clear subduction signature, others have chemical compositions that resemble those of the alkalic intraplate lavas of the Mexican Extensional Province (Luhr et al., 2006), located immediately north of Valle de Santiago.

The volcanic front (i.e. the locii of Holocene or active volcanism) of the western and central parts of the Mexican Volcanic Belt is located along an imaginary line that joins the historically active volcanoes Colima, Paricutin, Jorullo, and Popocatepetl (Figure 3) . Quaternary cinder cones and maars as young as $0.07 \mathrm{Ma}$ (K-Ar: Murphy, 1986) of the Valle de Santiago region are located $100 \mathrm{~km}$ north of the volcanic front as a consequence of a pronounced indentation in the volcanic front known as the Tzitzio gap (Blatter and Hammersley, 2010). In addition to the young cinder cones and maars, in the region around Valle de Santiago midsize continental calc-alkaline lava shields occur, which are older (K-Ar up to $6.8 \mathrm{Ma}$ ) and commonly have chemical compositions which are different from that of the mildly alkaline to alkaline cinder cones and maars (Murphy, 1986). Some of the Valle de Santiago maars were excavated in these older lava shields, as at La Alberca and Rincón de Parangueo maars, where the andesitic lava flows of the 


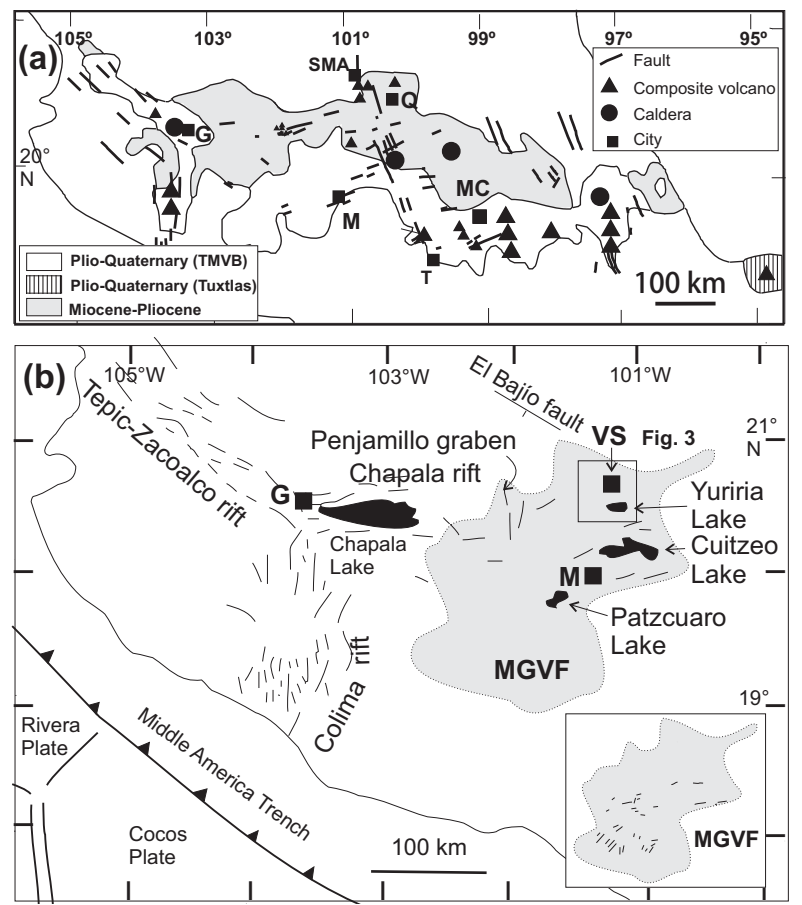

Figure 2 . The younger volcanoes of the TMVB are located near the Middle America trench. Near Guadalajara $(G)$ is a triple junction where three active rifts intersect. The Michoacán - Guanajuato Volcanic Field (MGVF) is located in the central part of the TMVB, west of the Taxco (T) - San Miguel Allende (SMA) fault system. Near the northwestern end of the MGVF are the N-S-trending Penajamillo graben and the N50W-trending El Bajío fault. Inset in figure (b) shows the volcanic lineaments identified by Connor (1990). Note that volcanic lineaments are roughly parallel to the convergence vector near the trench and parallel to the Chapala graben located farther north. Other localities: $\mathrm{Q}=$ Querétaro, $\mathrm{M}=$ Morelia, $\mathrm{MC}$ $=$ México City, VS $=$ Valle de Santiago.

older shield volcanoes are clearly exposed on the walls of the maar craters.

The outcrop geology of the region around the town of Valle de Santiago is dominated by volcanic features. In the area covered by the map in Figure 4 and its immediate surroundings we have recognized at least 50 cinder cones, 17 maar-type volcanoes and 15 lava shields. North and east of the town is a broad plain covered by alluvium, which probably represents the bottom of an extensive paleolake. Yuriria Lake, located $15 \mathrm{~km}$ south of Valle de Santiago, probably represents the remnants of the paleolake. The phreatomagmatic volcanoes define a rough $\mathrm{N} 25 \mathrm{~W}$-trending, $50 \mathrm{~km}$ long alignment of volcanoes (Figures 1 and 4). Cinder cones around Valle de Santiago define lineaments with two different orientations (N45W and $\mathrm{N} 80 \mathrm{E})$ and the lava shields apparently are randomly distributed in the area. The NW-trending alignments appear to be related with Neogene normal faults exposed at the boundary between El Bajío and Sierra de Guanajuato, and the ENE-trending alignments with a conspicuous late Cenozoic normal fault system exposed south of Yuriria Lake (Figure 4). Hasenaka and Carmichael (1985) reported a total of 20 maar type volcanoes in the

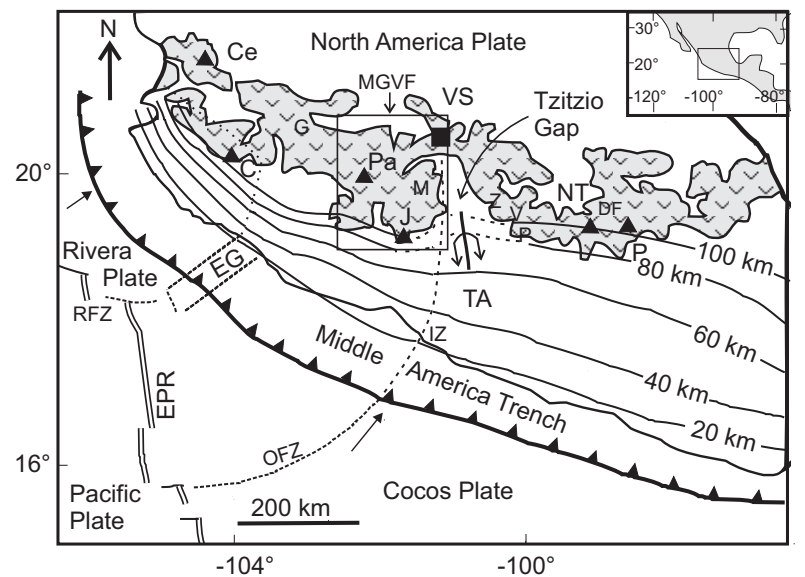

Figure 3. Quaternary volcanism in the TMVB is shown in dark gray . Inset box shows the area covered by the figure. The tectonic features on the ocean floor are modified from Pardo and Suárez (1995) and abbreviations are: $R F Z=$ Rivera Fracture Zone, EG=El Gordo Graben, EPR=East Pacific Rise, and OFZ=Orozco Fracture Zone. The depth to the subducting slab in km (from Pardo and Suárez, 1995) is shown with solid black contours. Abbreviations: MGVF=Michoacán-Guanajuato Volcanic Field (Hasenaka and Carmichael, 1985), VS=Valle de Santiago, NWVB=Northwest Volcanic Belt, $\mathrm{A}=$ Amealco Caldera, $\mathrm{M}=$ Morelia, $\mathrm{Z}=\mathrm{Zitácuaro}, \mathrm{V}=$ Valle de Bravo, $\mathrm{P}=\mathrm{El}$ Peñón, TA=Tzitzio Anticline, $\mathrm{NT}=$ Nevado de Toluca, $\mathrm{DF}=$ Distrito Federal (México City), $\mathrm{G}=$ Guadalajara, $\mathrm{IZ}=$ Ixtapa Zihuantanejo, $\mathrm{J}=$ Jorullo, $\mathrm{C}=$ Nevado de Colima, and $\mathrm{Ce}=$ Ceboruco. (Simplified from Blatter and Hammersley, 2010).

Michoacán - Guanajuato volcanic field; most of them are in the Valle de Santiago area. These facts argue about special hydrological and volcano-tectonic conditions in the region, as compared with the rest of the Michoacán - Guanajuato volcanic field, where both maars and volcanic lineaments are generally scarce, and those recognized are parallel to the direction of the plate convergence (N20-40E: Figure 2b) and located at the southern end of the field (Connor, 1990). Thus, the maar lineament may follow a tectonic feature (fault?) that controlled magma ascent and the maar abundance may signal the presence of a large lake in the area at the time when maars were formed (Aranda-Gómez et al., 2002).

\section{Regional tectonic setting}

The area between Querétaro and Valle de Santiago is located at the intersection of three regional fault systems (Figures 1 and 2b): Taxco - San Miguel de Allende (N20W), Chapala rift (N70E) and El Bajío (N50W). All these structures have had Neogene or Recent activity (e.g. Suter et al., 1995) and together with the volcanic edifices control the landscape in the region.

The Chapala rift (or Chapala - Tula fault system: Johnson and Harrison, 1990) runs approximately ENEWSW in the northern part of the MGVF (Figure 2), but the rift morphology is not as evident as in the other two rifts in the western portion of the TMVB: the Colima and the Tepic - Zacoalco rifts (Hasenaka, 1992a). The 


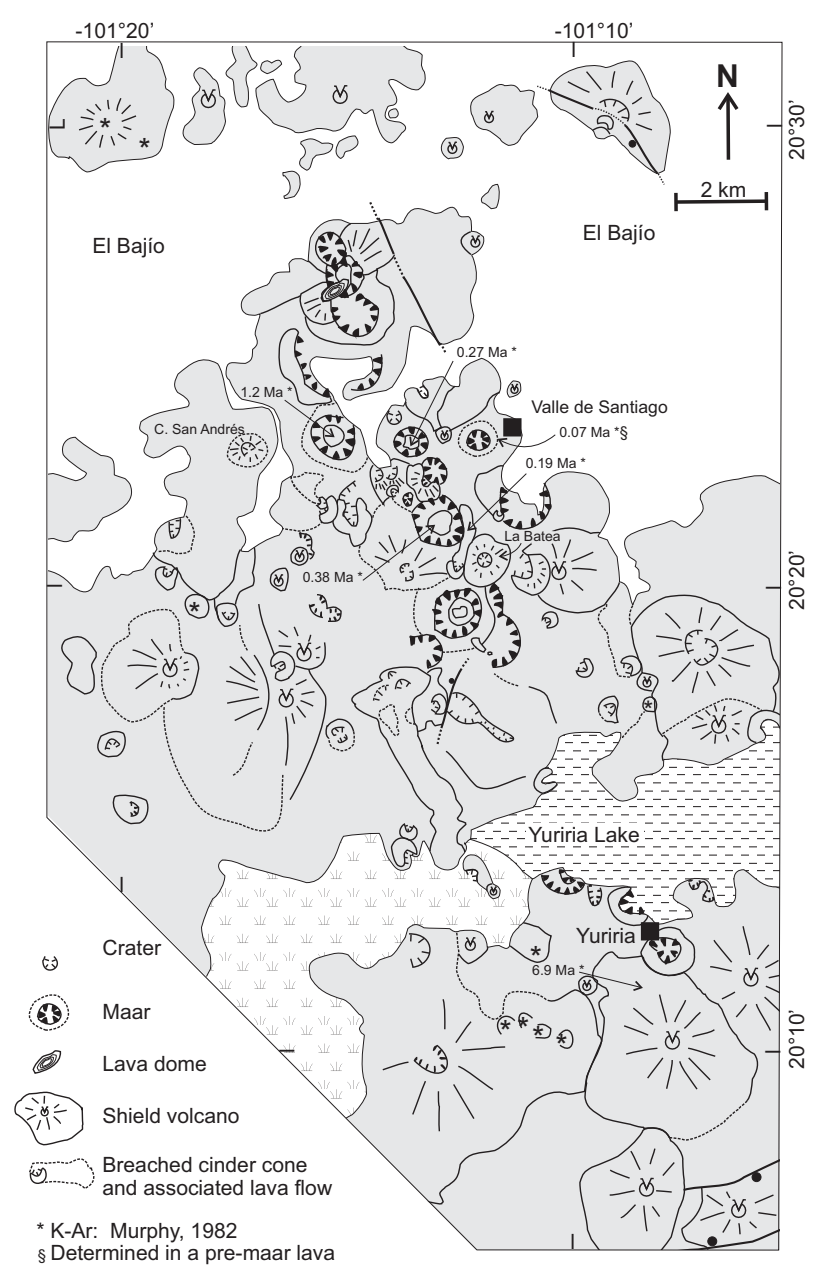

Figure 4. Photogeologic map of the Valle de Santiago region. ENE-trending normal faults in the SE corner of the map are part of the Chapala rift.

Pátzcuaro, Chapala, Cuitzeo and Yuriria lakes occupy tectonic depressions at the Chapala rift (Figure 2b). Some of the medium sized volcanoes of the MGVF are cut and offset by the normal faults (Hasenaka, 1992b) of the rift. In addition to the ENE-WSW trend of normal faults, in the northern portion of the MGVF is at least one N-S trending graben (Figures 1 and 2b). Shield volcanoes appear to be absent near this structure (Hasenaka, 1992b). This graben was described by Martínez-Reyes and Nieto-Samaniego (1992) as the Penjamillo graben (Figure 1) and it may still be active (Johnson and Harrison, 1990).

The Taxco - San Miguel Allende fault system is $\mathrm{a} \approx$ $\mathrm{N} 25 \mathrm{~W}$-trending set of structures that crosses the TMVB (Demant, 1978) and is buried by its products. The MGVF appears to end on its northeastern part at the Taxco - San Miguel Allende fault system. There is geophysical evidence that the Taxco - San Miguel Allende fault system is a major crustal discontinuity (Soler-Arrechalde and UrrutiaFucugauchi, 1993; Molina-Garza and Urrutia-Fucugauchi, 1993; Urrutia-Fucugauchi et al., 1995; Arzate et al., 1999) that separates two segments in the TMVB with contrasting morphology and styles of volcanism (Figure 1). Caldera and lava dome complexes of intermediate to felsic composition and associated ignimbrites are common east of the fault system. On the downthrown side of the fault system is the MGVF and the broad plain known as El Bajío, which is locally interrupted by shield volcanoes and cinder cone and maar complexes (Figure 1).

\section{Cinder/scoria cones, maars, tuff rings, and tuff cones}

All these are monogenetic volcanoes built up by the products of a single eruption (e.g. Cas and Wright, 1988). Cinder/scoria cones are formed by subaerial strombolian eruptions of basalt or basaltic andesite; there is not a significant amount of external water involved in their formation. Young cinder/scoria cones are usually circular in plan view and crowned by a bowl-shaped crater. Cone basal diameter $\left(\mathrm{W}_{\mathrm{Co}}\right)$ ranges from 0.25 to $2.5 \mathrm{~km}$ (mean $0.9 \mathrm{~km}$ ), cone height is $\approx 0.18 \mathrm{~W}_{\mathrm{Co}}$, and crater width $\approx 0.40$ $\mathrm{W}_{\mathrm{Co}}$. Fresh (young) cinder/scoria cones have steep outer slopes of about $33^{\circ}$ that reflect the angle of repose of the material. Pyroclastic deposits in cinder/scoria cones are poorly bedded, coarse- to very coarse grained, sometimes oxidized, highly vesiculated and glassy scoria with ballistic blocks and bombs. Cinder/scoria cones are very susceptible to erosion, which significantly changes their morphology with time.

Maars (sensu stricto), tuff rings and tuff cones are related to phreatomagmatic activity; external water is abundant in these eruptive systems and usually comes from an aquifer, river, lake or coastal region. A maar (sensu stricto) is a crater cut into the country rock and it is surrounded by a pyroclastic deposit where bedding dips gently outwards. The size of a maar crater ranges from a few hundred meters to 3 kilometers and their walls are steep or vertical. Fragments of the country rock are abundant in the pyroclastic deposit and in some cases may form nearly $100 \%$ of the deposit. Young maars have crater depth-to-diameter ratios of 1:5, but this ratio tends to increase with age as craters become infilled with sediments produced by erosion and accumulated in shallow lakes at the crater's bottom.

Tuff rings have craters that lie on or above the pre-maar surface; thus pre-maar rocks are not exposed in the crater walls. Bedding in the pyroclastic deposit dips gently both inwards and outwards of the crater; their size is similar to that of the maars (sensu stricto). Juvenile material tends to be more abundant than in maars and the composition of the magma may vary between basaltic and rhyolitic.

Tuff cones also have their craters above the pre-maar surface. They differ from tuff rings by having comparatively smaller craters and having higher height to width ratios. Bedding angles are $20-25^{\circ}$ and the pyroclastic deposits associated tend to be more lithified than in maars (sensu stricto) and tuff rings. 


\section{Origin of maars (sensu stricto)}

Lorenz (1986) proposed a model for the formation of maars (sensu stricto). According to his model, a diatreme (a cone-shaped, tuff-filled pipe that extends into igneous feeder dikes at depth) is produced underneath the maar crater as a consequence of the explosive interaction between hot magma, with temperatures up to $1100^{\circ} \mathrm{C}$, and meteoric water. In order to produce a phreatomagmatic explosion, the almost instantaneous vaporization of the water must occur under confining pressure. This could easily be achieved if the interaction occurs below the Earth's surface, where lithostatic pressure rapidly increases. However, confining pressure can not exceed the critical point of water (373 ${ }^{\circ} \mathrm{C}, 218$ bars) and probably is much less than 218 bars. In his model, Lorenz (1986) assumes that water - magma interaction occurs at depth where pressure is in the order of 20 - 30 bars. Phreatomagmatic explosions cause magma and country rock fragmentation around the site of mixing and ejection of the fragmented material (juvenile pyroclasts and accidental fragments) as pyroclastic flows (hot, water vaporrich, density currents) and ballistic fragments. Each one of the explosions forms a transient crater as a consequence of removal of fragmented country rock. The diameter and depth of the transient craters increases as the eruption continues. A key aspect in Lorenz' model of formation of a maar (sensu stricto) is that water comes from an aquifer with a reduced hydraulic conductivity. Thus, the effect of the phreatomagmatic explosions is to consume water from a relatively small volume in the aquifer and cause the formation of a temporary cone of depression due to local drawdown in the immediate vicinity of the explosion site. As the eruption continues, the cone of depression may steadily grow and the focus of the explosions must be shifted downwards as a consequence of the deepening of both the cone of depression and the transient craters. In some cases the aquifer in the immediate vicinity of a volcanic conduit may become momentarily dry, and the activity may shift to a regular strombolian type eruption and a cinder or spatter cone starts to build inside the maar crater. A renewed input of water into the volcanic conduit may cause new phreatomagmatic explosions and destroy the transient strombolian cone inside the crater. If water is not able to reach the volcanic conduit, or if the mixing conditions for explosive magma - water interaction are not met, growth of the cinder cone and/or formation of a lava lake inside the crater may occur, such as it happened in La Breña (Aranda-Gómez et al., 1992). A good example of this behavior can be seen at Hoya Blanca, located $2 \mathrm{~km}$ SW of the center of La Alberca (Figure 5). Once the magma ascent thru the volcanic conduit stops, water in the aquifer may flow back into the region where the temporarily cone of the depression was formed, and the crater is commonly filled by a perennial lake. The surface of the lake inside the crater coincides with the water table in the regional aquifer. Locally, water chemistry may be altered by the presence of hydrothermal fluids or gases associated with

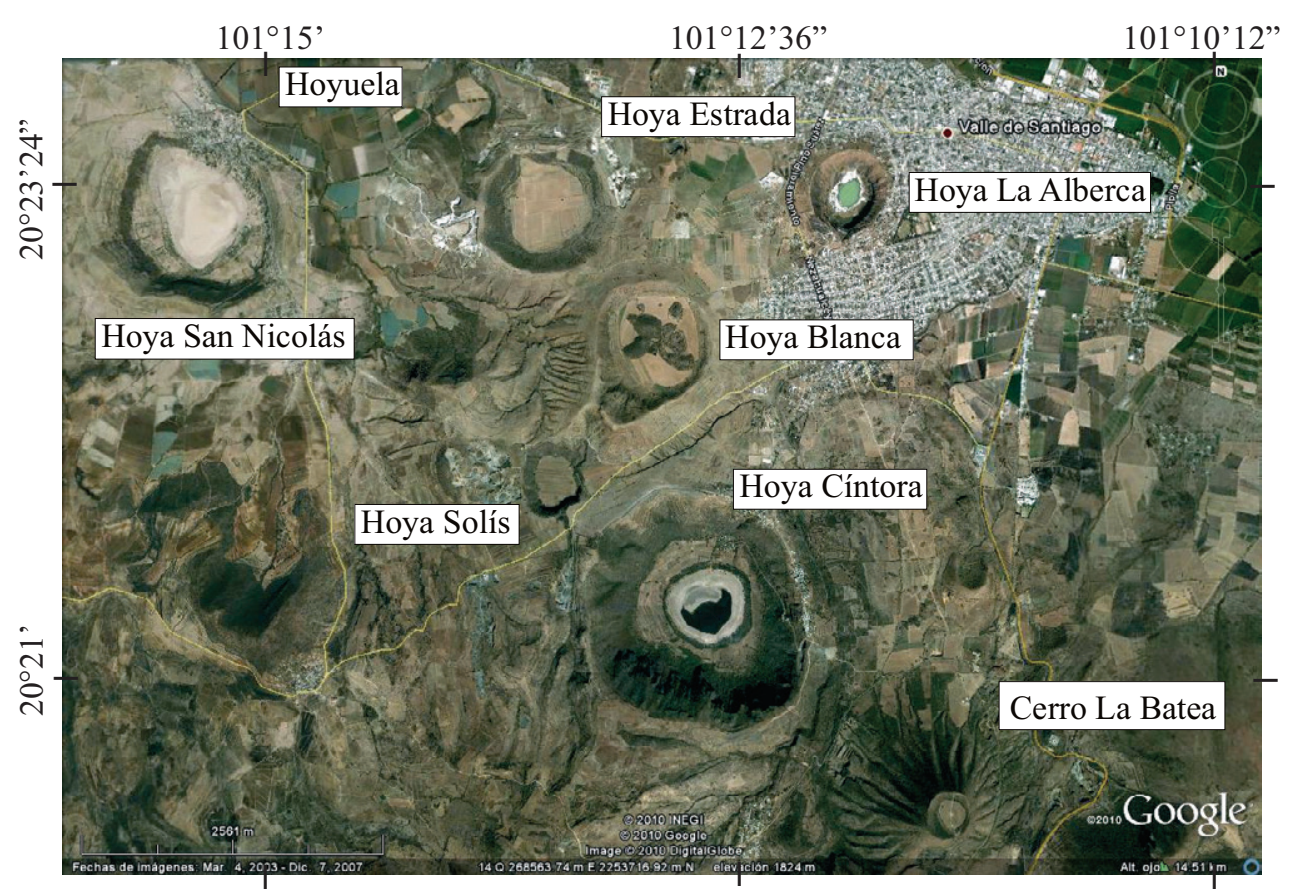

Figure 5. Volcanoes near Valle de Santiago, Guanajuato. San Nicolás, Alberca, and Cíntora are good examples of maars (sensu stricto) as older rocks are exposed on the craters walls. Hoya Estrada is an example of a tuff-ring. Inside the crater of Hoya Blanca exist the remnants of several cinder/scoria cones; these volcanoes grew inside the maar when the system ran out of water. Note the marked contrast in the morphologies of Cerro La Batea (a cinder cone plastered with surge deposits from neighboring maars) and the maar-type volcanoes 
the formation of the maar; this may explain the pronounced contrast between the water composition inside the Rincón de Parangueo maar and water in other portions of the aquifer.

\section{Land subsidence and groundwater drawdown}

Land subsidence is the lowering of the land-surface elevation caused by underground changes. Land subsidence is commonly related with excessive groundwater pumping, and/or intense oil and/or gas extraction. Subsidence is also linked to limestone or evaporite solution by groundwater and to collapse of underground mines, hydrocompaction (initial wetting of dry soils) and drainage of organic soils (Leake, 2010).

Aquifer systems that are susceptible to trigger land subsidence are those that are bounded by or contain silt and clay interbeds. Lowered water pressure in sand or gravel beds reduces the water pressure and causes slow drainage of water from the interbedded clay and silt layers. Because these beds are compressible, they compact, causing land subsidence at the surface. Differential compaction within the system causes the formation of fractures and relative displacement of blocks separated by the fractures.

The region around Valle de Santiago, also known as El Bajío plain is characterized by intensive agriculture. Water for irrigation comes from the Ignacio Allende reservoir $\left(20^{\circ}\right.$ $50.879^{\prime} \mathrm{N}, 100^{\circ} 49.548^{\prime} \mathrm{W}$ ) or from pumpage of numerous water wells. The Valle de Santiago - Salamanca aquifer has an estimated area of $1700 \mathrm{~km}^{2}$ and provides water for 800000 people. There are about 1600 active wells that extract about $646 \mathrm{Mm}^{3} / \mathrm{yr}$. Drawdown rate in the past 25 years is calculated as $2 \mathrm{~m} /$ year. The extracted water is used as follows: agriculture $81 \%$, urban supply $10 \%$, industry $8 \%$, and cattle raising $1 \%$ (Mejía and Sandoval, 2004).

Fracturing and formation of active aseismic faults is one of the consequences of land subsidence. This phenomenon is common and widespread in the regions where cones of depression have been formed by intense groundwater pumping in areas with a high density of wells. Land subsidence-related active fractures have been documented in many urban areas of El Bajío and nearby regions, such as Querétaro (Pacheco-Martínez, 2007), Celaya, Salamanca, Abasolo, Silao, and Irapuato (Figure 1).

\subsection{Celaya}

A dramatic example of these active faults may be observed at the Alameda Park in downtown Celaya $\left(20^{\circ}\right.$ $\left.31.687^{\prime} \mathrm{N}, 100^{\circ} 48.531^{\prime} \mathrm{W}\right)$. In the area located between Guillermo Prieto and Agustín Arroyo streets damage to the buildings and pavement has been very intense. Fault displacement at this point is estimated at $2.4 \mathrm{~m}$, forcing the municipality to build stairs on the sidewalks. The building located between Guillermo Prieto and Agustín Arroyo streets was partially demolished and reconstructed leaving a garden along the fault trace. After the repairs, movement has continued, as it is attested by damage to the newly built portions of the stores.

Figure 6a, based on InSAR data obtained and processed by Ávila-Olivera (2009), shows the areas in Celaya where land subsidence occurred in the period 11/02/06 $27 / 05 / 06$. Areas with maximum displacement are located in the downthrown side of the Oriente and Universidad Pedagógica faults and in two broad areas in the NE and SE portions of the city. Subsidence in the order of 2-3 cm occurred in the graben bounded by the N30W trending faults in a three month period, so the annual rate of sinking could be as much as $7-10 \mathrm{~cm}$ in that zone. A differential InSAR interferogram (Figure 6b) for a 455 day time span (16/08/2003-13/11/2004) shows similar features and an additional area where subsidence is occurring, probably associated with heavy groundwater extraction to provide water for a newly opened industrial zone (Ávila-Olivera et al., 2010).

Land subsidence and faulting is known in Celaya since the 1950s. However, the first written accounts about this phenomenon date back to 1985 , when only the Oriente and Poniente faults (Figure 6a, 6b) were known (TrujilloCandelaria, 1985). Maximum length and throw along the Oriente fault in 1985 were $4 \mathrm{~km}$ and $1.5 \mathrm{~m}$, respectively. By 2005 maximum length and throw for this structure were 11.2 $\mathrm{km}$ and $3.10 \mathrm{~m}$, respectively (Huízar-Álvarez et al., 2010). It is worth mentioning that close to the Querétaro - León toll road (point A in Figure 6a) the throw in the fault is still in the order of $0.5 \mathrm{~m}$, so we believe that the fault must extend along its trend towards the NW; however, the trace of the structure is hard to follow in the agricultural land located north of the toll road. Thus the length reported by HuízarÁlvarez et al. (2010) may be a conservative estimate.

Radargrams obtained by Giordano et al. (2010a) at several points of the Oriente fault have shown that the fault plane is almost vertical close to the surface $(\leq 15 \mathrm{~m})$ and there is a set of synthetic faults with $40-45^{\circ}$ inclination in the downthrown (NE) side of the structure. This information shows that fault effects extend up to $30-35 \mathrm{~m}$ on each side of the fault. Thus the potential zone of damage may be as wide as $70 \mathrm{~m}$. This may be the explanation for the damage in the repaired buildings and for fractures oriented N70E in the auditorium of the XVII century San Francisco convent in downtown Celaya.

Based on GPS information, measured in 32 control points inside the city and referred to a fixed point located at a lava flow in the outskirts of La Gavia volcano (Figure 1), subsidence rate in Celaya may be as high as $10-14 \mathrm{~cm} /$ year and in a few anomalous points there is local uplift of $3.5 \mathrm{~cm}$ (Díaz-Salmerón et al., 2010).

Extraction of groundwater in Celaya began in 1910. As population increased and irrigation was adopted in the area, total extraction and number of active wells increased. In 1985, 2200 wells were pumping out $538 \times 10^{6} \mathrm{~m}^{3} /$ year of water from the Celaya's aquifer. The most recent well 

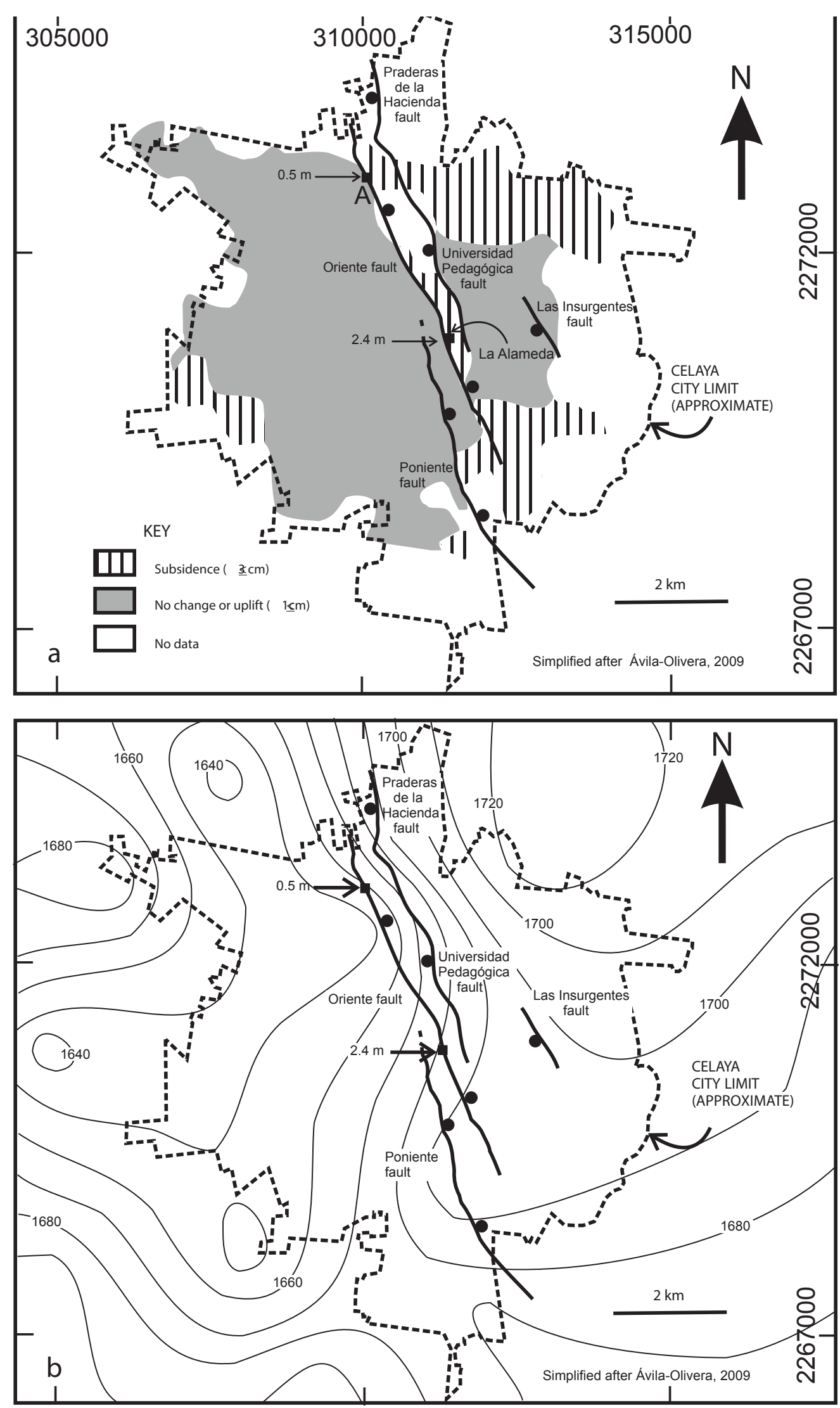

Figure 6. a) Land subsidence in Celaya as inferred by Ávila-Olivera (2009) and Ávila-Olivera et al. (2010) from InSAR data in the period 11/02/06 27/05/06. b) The same figure, showing piezometric isolines (elevation given in meters above sea level) in 2007. Subsidence-related faults coincide with the boundary between two domains in the piezometric surface; east of the faults the surface is shallower (Ávila-Olivera, 2009). 
census (2008) indicates that there are 2000 active wells extracting $600 \times 106 \mathrm{~m} 3 /$ year of water. Today a total of 205 wells provide water for domestic and industrial use in Celaya. Drawdown in the order of $170 \mathrm{~m}$ occurred in the time period 1980 - 2003 in Celaya (Huízar-Álvarez et al., 2010). Subsidence associated faults appear to reflect in the surface the trend of buried structures such as a NNW-trending horst (Giordano et al., 2010b). This hidden structure may be related to the Taxco - San Miguel Allende fault system (Figure 1)

\subsection{Salamanca}

A N70E-trending, subsidence-related, active fracture occurs $14 \mathrm{~km}$ north of the center of the Rincón de Parangueo maar (Figure 1), near the Salamanca oil refinery (Borja-Ortíz and Rodríguez, 2004). The estimated displacement rate in this man-induced normal fault is $\approx 6 \mathrm{~cm} /$ year. This N70Etrending, down to the SE fault with an estimated throw $<$ $0.5 \mathrm{~m}$ is well exposed on Héroes de Cananea Street $\left(20^{\circ}\right.$ $\left.34.224^{\prime} \mathrm{N}, 101^{\circ} 11.014^{\prime} \mathrm{W}\right), 280 \mathrm{~m}$ south of the refinery. The fault can also be seen on the outer walls of the refinery at the Faja de Oro $\left(20^{\circ} 34.304^{\prime} \mathrm{N}, 101^{\circ} 10.770^{\prime} \mathrm{W}\right)$ and José Vasconcelos streets $\left(20^{\circ} 34.372^{\prime} \mathrm{N}, 101^{\circ} 10.524^{\prime} \mathrm{W}\right)$. At the José Vasconcelos locality the fault trace is a few meters away from a set of elevated ducts between the main body of the refinery and subsidiary installations belonging to Gas y Petroquímica Básica de Pemex, which is a branch that processes, transports and commercializes natural gas, liquid hydrocarbons and basic petrochemical products, such as ethane, gasoline and sulfur (PEMEX, 2010).

There is evidence of subsidence-related faults in Salamanca since the early 1980 's. The refinery fault has a measured length of $12 \mathrm{~km}$; the width of the damaged area on both sides of the trace is $\sim 50 \mathrm{~m}$. This particular structure can be projected across El Bajío plain to Juventino Rosas $\left(20^{\circ} 38.540^{\prime} \mathrm{N}, 100^{\circ} 59.557^{\prime} \mathrm{W}\right)$, a town located $22 \mathrm{~km}$ ENE of Salamanca (Figure 1). A subsidence-related fault at Juventino Rosas has a maximum displacement of $2 \mathrm{~m}$ and follows the same trend as the refinery fault (Borja-Ortíz and Rodríguez, 2004).

The Valle de Santiago-Salamanca aquifer has a high well density (Mejía et al., 2001). The Lerma River divides the Salamanca urban area as well as the subsurface geology. Shallow stratigraphy north of the river is dominated by fine-grained sediments, whereas south of the river coarsergrained volcanic successions prevail. The river is also an aquifer division; north of the river three aquifer bodies have been identified (shallow, intermediate, and deep). The shallow aquifer water table is $18-20 \mathrm{~m}$ deep (Mejía et al., 2007). The water table in the intermediate body is $30-35$ $\mathrm{m}$ below the surface and it is $70-80 \mathrm{~m}$ in the deep aquifer (Borja-Ortíz and Rodríguez, 2004). Average well depth in the intermediate aquifer is $150 \mathrm{~m}$ and water temperature is $\sim 24^{\circ} \mathrm{C}$; most wells used to produce water for domestic and agricultural use in the area pump out water from the intermediate aquifer. Water in the deep aquifer comes from fractures in rhyolitic lava flows and has temperatures between 29 and $38{ }^{\circ} \mathrm{C}$ and high boron content.

The role of the refinery fault in aquifer vulnerability has been investigated by several researchers. Rodríguez (2004) found that hydraulic conductivity significantly increases at the fault; 70 permeability measurements along the trace of the fault show that hydraulic conductivities increase from $\left(2.5 \times 10^{-8} \mathrm{~m} / \mathrm{sec}-6.0 \times 10^{-7} \mathrm{~m} / \mathrm{sec}\right)$ to $\left(8.0 \times 10^{-3} \mathrm{~m} /\right.$ $\mathrm{sec}-6.0 \times 10^{-5} \mathrm{~m} / \mathrm{sec}$ ). In addition to damaging buildings and pavement the fault also breaks drinking water and sewage pipelines. Volume estimates of the leakages are in the order of 25 and $30 \%$ for drinking and sewage waters, respectively. Salamanca is located in a semi-arid area where infiltration and local recharge is very low as a consequence of runoff and evapotranspiration. According to Rodríguez (2004) data, leakages from the piping systems in Salamanca may locally add a comparable amount of artificial recharge.

There is some evidence of interaction between the three aquifer bodies north of the Lerma River. For example, both the shallow and intermediate aquifer bodies have depression cones around a shallow well located near the fault trace. As the shallow body is not being intensively exploited because it is highly contaminated, it follows that water pumping in the intermediate body exerts some influence in the behavior of the shallow body. Likewise, high boron content in the three levels is interpreted as evidence that the deep aquifer interacts with the other two bodies (Mejía et al., 2007). It is not known if this is occurring as a consequence of the presence of tensional faults/fractures or through wellbore flow in wells screened over multiple aquifers (multi-aquifer wells).

There are reports of groundwater contaminated with hydrocarbons near the refinery since the 1980s. Turati (2008) summarized these occurrences in an article published a few years ago in Excelsior, a Mexico City newspaper. According to Turati's account, in a place called Bar La Falla (The Fault Bar: $20^{\circ} 34.140$ 'N $101^{\circ} 11.203^{\prime} \mathrm{W}$ ), located on the Refinery fault trace, a water well tapping the shallow aquifer contained hydrocarbons in 2007.

The radically different orientation of the land-subsidence fault in Salamanca, as compared to those in Celaya, may reflect a different tectonic fabric in the underlying basement (Figure 1). The N70E-trend of the subsidence faults agrees well with the orientation of the Chapala rift, which is conspicuously exposed south of nearby Valle de Santiago (Figure 4). However, the Chapala rift fault orientation in the area between Valle de Santiago and Salamanca is obscured by the lacustrine basin fill.

\section{Valle de Santiago maars}

The first geologic study of the volcanoes around Valle de Santiago was made by Ordóñez in 1900, which clearly recognized their phreatomagmatic origin. Four crater-lakes 
existed in the area in 1900: La Alberca, Hoya San Nicolás, Hoya Cíntora, and Hoya Rincón de Parangueo, prior to the intensive overdraft in the Valle de Santiago - Salamanca aquifer (Figure 7). Today there are only small pools of water in all of them during and after the rainy season.

\subsection{Hoya La Alberca}

Hoya La Alberca is a quasi-circular-shaped crater 700 $\mathrm{m}$ in diameter. It is at the eastern end of an E-W alignment of four maars (Figures 4 and 5: San Nicolás, Estrada, Hoyuela, and La Alberca) that intersect with a dominant, NW-trending, regional alignment of maars (Figures 1 and 4). In general, volcanic lineaments are interpreted as evidence of a structural control on the location of volcanism (e.g. Nakamura, 1977); it is commonly assumed that magma reaches the surface through extensional fractures or faults. Joints and faults in hard rock (e.g. in the continental lava shields) also produce hydraulically active domains where groundwater is available in fracture-controlled aquifers (Lorenz, 2003).

"Hoya" means pit. "Alberca" signifies pool, because for many years in the past decades this crater-lake was used as a swimming pool (there is the framework of an abandoned springboard on the SW wall of the crater). The lake at the bottom of the crater was permanent (Figure 8a) as it was fed by the Valle de Santiago - Salamanca aquifer. Today, there is

Mem. Soc Alzate. Mexico.

Tom. XIV. Planche V.

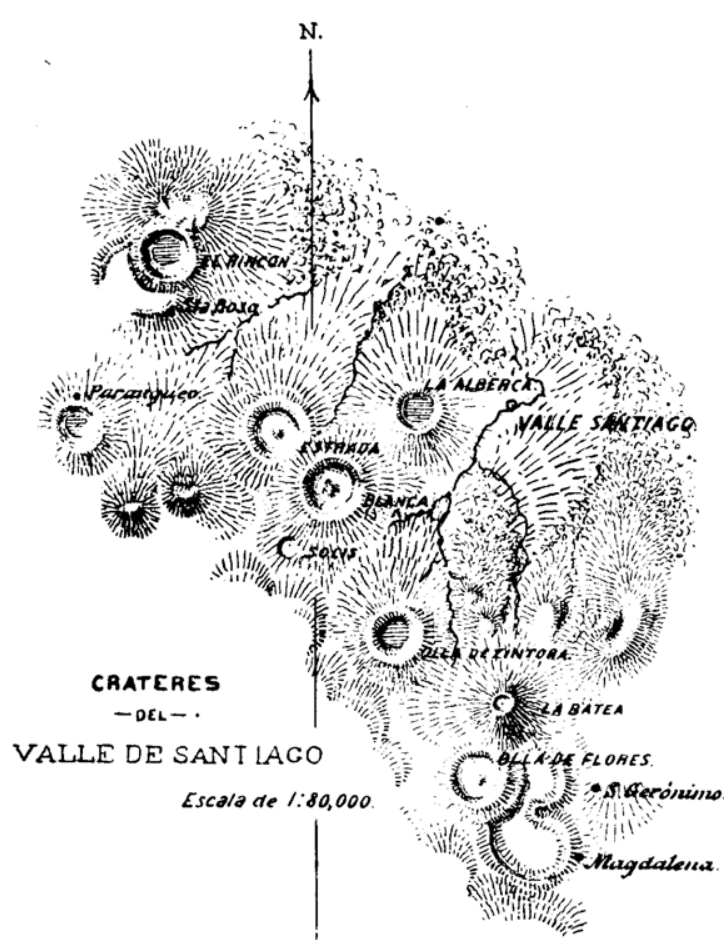

Figure 7. Ordoñez's 1900 map of the Valle de Santiago volcanoes. Perennial crater-lakes in 1900 are marked with a horizontal line pattern. no longer a permanent lake inside the crater (Figure 8b, 8c) as a consequence of overdraft in the aquifer; the maximum level the lake attained in the recent past is clearly marked with salts on the walls of the crater (Figure $8 \mathrm{~b}$ ). Based on the height difference between the mark on the wall and the bottom of the dry lake bed and the date when the crater was desiccated, Escolero-Fuentes and Alcocer-Durand (2004) estimated a drawdown rate for the Valle de Santiago Salamanca aquifer of $2.6 \mathrm{~m} /$ year.

Stromatolites colonies that are exposed on the NE wall of La Alberca grew attached to the nearly vertical walls of the pre-maar lavas. The most common structures found at La Alberca are botryoidal and column-like aggregates with clear concentric layers of $\mathrm{CaCO}_{3}$. Stromatolites are microbialites, which are "a sedimentary body...[made] from the remains of benthic communities of algae and cyanobacteria" (Allaby and Allaby, 1999).

The local geology of Hoya La Alberca is exposed on the crater walls (Figure 8c). Pre-maar rocks are andesitic lava flows with conspicuous vertical joints. These lavas are not related to the formation of La Alberca crater. The andesitic pre-maar lavas were dated by the Ar/Ar method at 0.25 +/$0.02 \mathrm{Ma}$ (Rincón, 2005). These lavas are separated from the maar-forming pyroclastic succession by a paleosol exposed at the base of the wall located immediately south of the parking lot. This paleosol represents a significant period of repose between the pre-maar andesite and the formation of the maar. Thus, field relations and the Ar/Ar date indicate that the maar is younger than $0.25 \mathrm{Ma}$.

Prior to the formation of the maar, a small scoria cone was constructed at the area now occupied by the crater. Remnants of the cone are exposed at the NE wall of the crater (Figure $8 \mathrm{~b}$ and $8 \mathrm{c}$ ). It is likely that the summit area, crater and feeding conduit of the cinder cone were located towards the center of today's maar crater. The scoria cone indicates strombolian activity, characteristic of "dry" magmatic eruption prior to water-magma interaction. The scoria cone was formed by relatively short-lived eruptive columns that produced scoria and ash that accumulated close to the vent. The lack of a paleosol between the scoriafall deposit and the phreatomagmatic succession suggests that this activity was the precursor eruptive signal, which occurred just before the initiation of the more violent, maarforming, phreatomagmatic explosions.

The pyroclastic succession produced by the maarforming eruption is exposed on the southern wall of the parking lot inside the crater and along the access road. Activity started with violent phreatic eruptions although there are beds that record phreatomagmatic blasts. This initial activity produced very efficient fragmentation of the country rock forming a succession dominated by fine-grained, laminated, surge deposits. Higher up in the pyroclastic succession the fine-grained beds alternate with massive heterolithologic breccias, coarse gravel deposits and unsorted layers with some blocks within a sandy-silty matrix. These coarser grained beds are interpreted as fall 

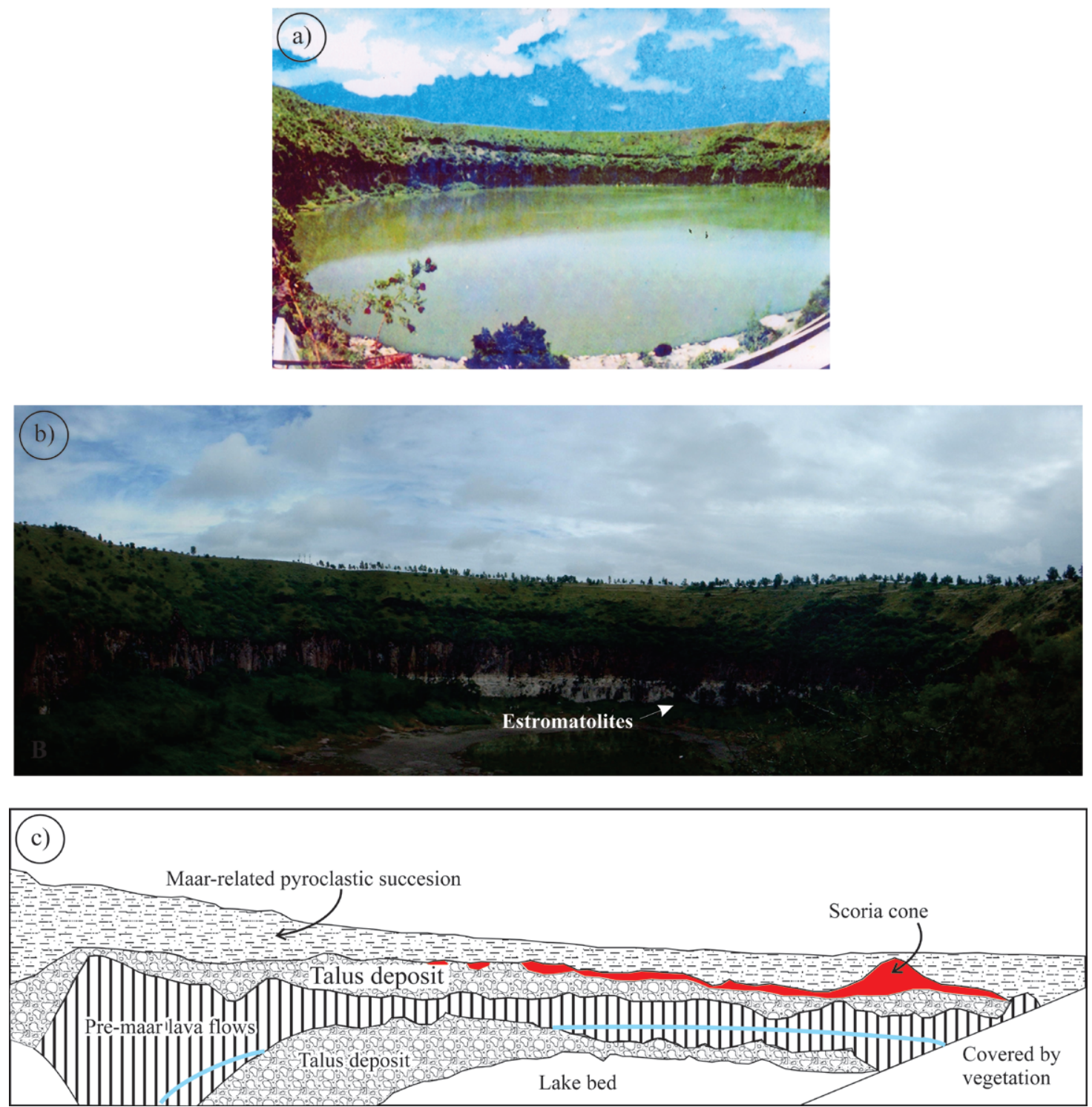

Figure 8. Panoramic views of La Alberca crater. a) The northern wall prior to desiccation process (date when photograph was taken is unknown, but probably before 1985. This photograph is sold as a postcard in Valle de Santiago). b) Approximately the same view, as seen in August 2010. Note that the small "playa-lake" has a slight red color, probably due to the presence of cyanobacteria in the water. c) Line drawing enhancing the main features shown in (b).

deposits. Some surge deposits include thin accretionary lapilli horizons suggesting wet conditions during the particle transport in surges (Brown et al., 2010). The overall nature of the pyroclastic deposit (i.e. the different clast proportions and structures in the succession) indicates wide variations in the water-magma ratio in the system, which produced marked changes in the efficiency of fragmentation of both juvenile and accidental components. Water-magma variations may reflect variable rates of magma injection and/or transient changes in the aquifer in the immediate vicinity of the vent (formation of a cone of depression and/ or temporary exhaustion of water). Changes in the watermagma ratio produced variable and rapid changes in the explosiveness during the eruption.

\subsection{Hoyas San Nicolás y Cíntora}

The topography of the bottom of the perennial lake that formerly occupied the San Nicolás crater is a smooth, gently curved, concave upward surface, without any evidence of post-desiccation sinking. A similar topography is observed both at La Alberca and Hoya Cíntora (Figure 9) between the talus deposits located at the base of the pre-maar lava flows and the depocenters. Poorly developed microbialites occur as thin crusts around rock fragments located at the former shores of the perennial lakes of San Nicolás and Cíntora. Similar crusts have been observed around rocks at the upper part of the littoral zone in the former Rincón de Parangueo Lake.

It is worth mentioning that microbialite development in 


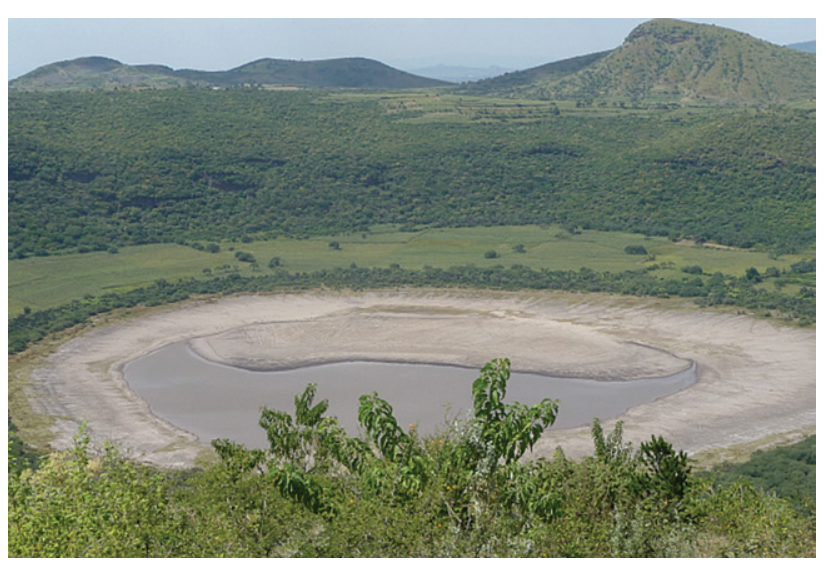

Figure 9. Panoramic view of the bottom of Hoya Cíntora as seen from $20^{\circ}$ $21.065^{\prime} \mathrm{N}, 101^{\circ} 12.359^{\prime} \mathrm{W}$ (see figures 4 and 5) for location. Note that the bottom of the crater is a gently curved, concave upward, surface with no evidences of subsidence. Poorly developed microbialites were found near the former shore, which is marked by the vegetation line.

all the maars appears to be related to the original salinity of the lakes. By far, the best developed and most extensive stromatolite ring is in Rincón de Parangueo, which has the most saline water (Tables 1 and 2). Note the marked increase in $\mathrm{Na}^{+}$concentration at La Alberca between 1981 and 1999, which we attribute to evaporation after desiccation. Unfortunately there are no reliable water analyses of all lakes prior to desiccation (see 1941 analysis in Table 1), but we note that once present day ephemeral lakes are desiccated, the thickness of the evaporite crust is Rincón de Parangueo $>>$ La Alberca $>$ San Nicolás $\approx$ Cíntora. Therefore, we believe that Rincón de Parangueo was always the most saline lake in the region.

\subsection{Hoya Rincón de Parangueo}

The Rincón de Parangueo maar is part of the Parangueo volcanic complex, which is formed by at least six volcanoes (Figure 10). The Quaternary phreatomagmatic volcanoes were excavated in an older trachyandesitic lava shield. A rhyolitic lava dome grew inside the crater of La Mina maar; its silica-rich composition contrasts with the intermediate or mafic composition of other volcanoes in the complex. The juvenile material of the Santa Rosa tuff ring yielded an Ar/ Ar age of $0.137+0.09 \mathrm{Ma}$ (Aranda-Gómez et al., 2009). Figure 11 is a panoramic view of the complex as seen from the south. The gentle outer slopes of the lava shield are obvious, as well as the Rincón de Parangueo maar crater and the rounded hill of the lava dome. The flat surface at the bottom of the tuff ring is a playa-lake during the wet season; it also represents the remnant of a larger paleolake. Figure 12 is an epipolar image which allows seeing a 3D map view (use of anaglyphs is required) of the complex.
Table 1. Chemical composition of La Alberca water (modified after Escolero-Fuentes and Alcocer-Durand, 2004). The 1941 data is based on Orozco and Madinaveitia (1941), which reported the existence of a spring that fed the crater-lake. Location of the spring is unknown.

\begin{tabular}{cccc}
\hline Ion & Spring & \multicolumn{2}{c}{ Craterlake } \\
$\mathrm{mg} / \mathrm{l}$ & 1941 & 1941 & 1981 \\
\hline $\mathrm{Na}$ & 102.2 & 2933 & 448 \\
$\mathrm{~K}$ & n.d. & n.d. & 88 \\
$\mathrm{Ca}$ & $\mathrm{Tr}$ & $\mathrm{Tr}$ & 6 \\
$\mathrm{Mg}$ & $\mathrm{Tr}$ & $\mathrm{Tr}$ & 70 \\
$\mathrm{SO}_{4}$ & 8 & 412 & 73 \\
$\mathrm{Cl}$ & 21 & 504 & 174 \\
$\mathrm{HCO}_{3}$ & 225 & 2127 & 811 \\
$\mathrm{CO}_{3}$ & 0 & 2094 & 204 \\
$\mathrm{NO}_{3}$ & n.d. & n.d. & 1 \\
\hline
\end{tabular}

$\operatorname{Tr}=$ trace; n.d. $=$ not determined.

\section{Active land subsidence and formation of landslides inside Rincón de Parangueo}

One of the most striking topographic features at the bottom of the Rincón de Parangueo maar is a steep scarp located between the center of the present day playa-lake and the former perennial lake shore. This landform, unique among the phreatomagmatic craters of the Valle de Santiago region, is probably related to land subsidence caused by lowering of the groundwater table during the past decades (Figure 13). Air photos taken in March 1984, close to the end of the dry season, show a nearly circular lake with a diameter of $1100 \mathrm{~m}$. Escolero-Fuentes and Alcocer-Durand (2004) reported that in 2003, just before the beginning of the rainy season, the lake was completely dry. The air photo shown in Figure 13c shows an important area at the bottom of the crater covered with water. Presumably this water was accumulated during the rainy season (May - September) of that year.

A close inspection of the topographic scarp in the former lake bottom suggests that active deformation is occurring in the maar. We interpret the scarp as the trace of an active, segmented, ring fault. Cumulative normal displacement in the ring fault is accomplished through a series of two or three concentric, high angle, step faults (Figure 14). In many places of the scarp rotational landslides occur (Highland, 2004) and structures such as dilatation crown fractures, transverse cracks and ridges, rotated blocks, antiforms, synforms, and areas of complex deformation may be observed. In several localities at the bottom of the crater we have recognized small dome structures that we attribute to mud injection associated with mass movements.

In the area located between a picnic area inside de crater $\left(20^{\circ} 25.602^{\prime} \mathrm{N}, 101^{\circ} 14.827^{\prime} \mathrm{W}\right)$ and the main topographic scarp at the former lake bed, a platform covered by a stromatolite biostrome is exposed. These 
Table 2. Field parameters and water chemistry of Rincón de Parangueo and La Alberca crater-lakes after the rainy season in 1999 (compiled from Armienta et al., 2008).

\begin{tabular}{|c|c|c|c|c|c|c|c|c|c|c|c|c|c|c|}
\hline & Depth & $\mathrm{T}\left({ }^{\circ} \mathrm{C}\right)$ & $\mathrm{pH}$ & $\Lambda(\mu \mathrm{S} / \mathrm{cm})$ & Tot alk & $\mathrm{Na}^{+}$ & $\mathrm{K}^{+}$ & $\mathrm{SO}_{4}{ }^{2-}$ & $\mathrm{Cl}^{-}$ & B & $\mathrm{SiO}_{2}$ & $\mathrm{CO}_{3}{ }^{2-}$ & $\mathrm{HCO}_{3}^{-}$ & Fecha \\
\hline Rincón & Surf & 18.1 & 10.2 & 165000 & 76000 & 4250 & 5070 & 76 & 64000 & 414 & 29 & 40000 & 12000 & oct-99 \\
\hline Rincón & $5 \mathrm{~m}$ & 23.6 & 10 & n.d. & n.d. & n.d. & n.d. & n.d. & n.d. & n.d. & n.d. & n.d. & n.d. & oct-99 \\
\hline Alberca & Surf & 21.3 & 9.6 & 11960 & 5825 & 3102 & 530 & 536 & 2400 & 13 & 11.3 & 2913 & 1185 & oct-99 \\
\hline Alberca & $4 \mathrm{~m}$ & 19.3 & 9.7 & 12460 & n.d. & n.d. & n.d. & n.d. & n.d. & n.d. & n.d. & n.d. & n.d. & oct-99 \\
\hline
\end{tabular}

$\mathrm{T}=$ temperature, $\Lambda=$ electric conductivity, Tot $=$ Total alkalies, Surf $=$ surface. All concentrations in parts per million.
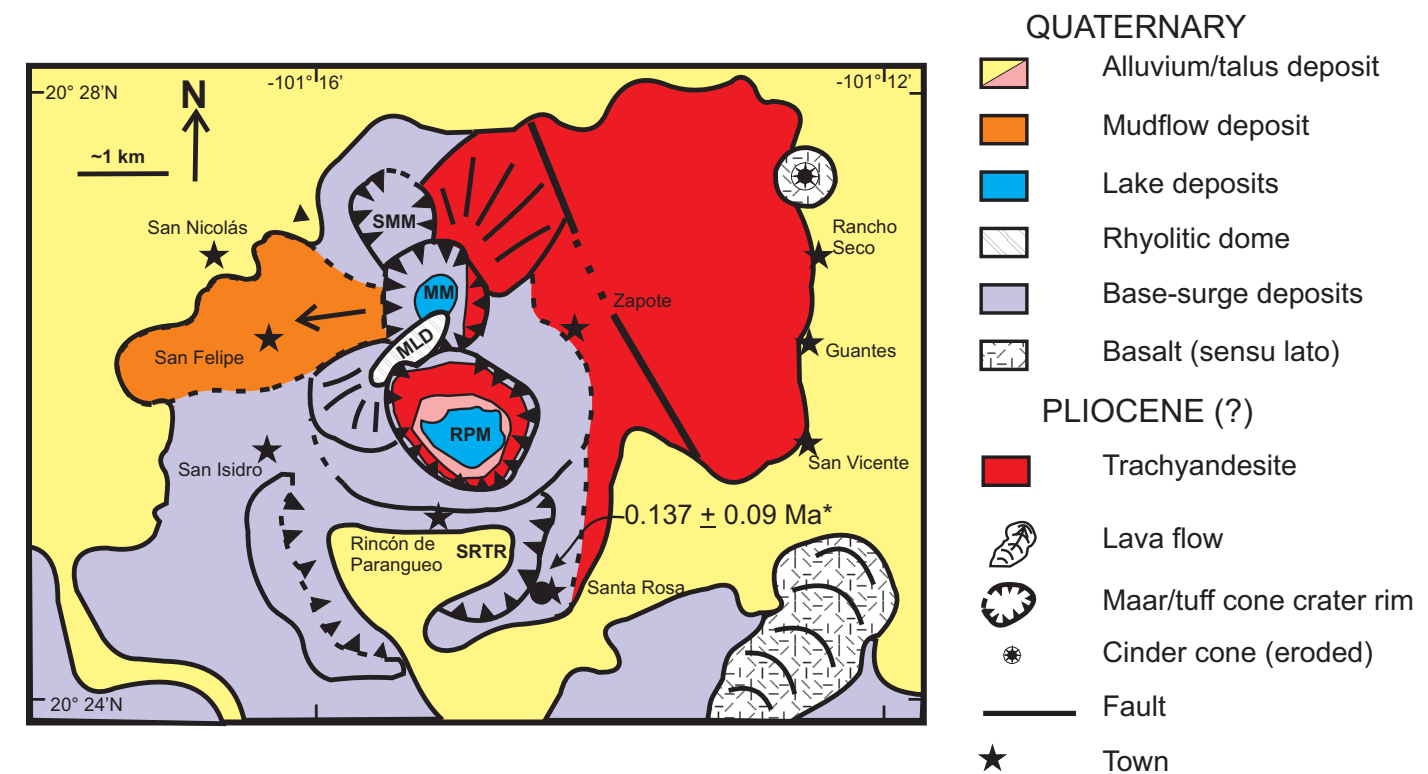

Figure 10. Geologic map of the Parangueo volcanic complex. Three maars (sensu stricto) were excavated in trachyandesitic continental lava shield. Remnants of a tuff ring are also exposed. A lava dome grew inside La Mina maar (MM) (Figure 11). Key: SMM= San Manuel maar, MLD = La Mina lava dome, RPM = Rincón de Parangueo maar, and SRTR = Santa Rosa tuff ring. Note that pre-maar older rocks in the walls of the tuff ring are not exposed.

$\mathrm{CaCO}_{3}$ precipitating algal or bacterial mats form a blanketlike mass of poorly indurated rock. Just at the edge of the platform several stromatolite bioherms (mound-like colonies) exist. The distinctive structure of the stromatolites is almost completely destroyed in the biostromal part of the ring as a consequence of heavy visitor traffic. However, these structures can easily be observed elsewhere in other areas near the main topographic scarp. Throughout this part of the platform adjacent to the picnic area there are fractures that mark the beginning of an incipient landslide (Figure 15a). Some of the tensional fractures are clearly open and may already have some vertical displacement. Other fractures are barely visible and lack displacement. As a general rule, cumulative vertical displacement in this fracture system gradually increases as one gets closer to the area where a roll-over fold (Figure $15 \mathrm{~b})$ is evident $\left(20^{\circ}\right.$ $\left.25.650^{\prime} \mathrm{N}, 101^{\circ} 14.763^{\prime} \mathrm{W}\right)$. Note that in the picnic area the stromatolite platform dips gently $\left(4^{\circ} \mathrm{SE}\right)$ towards the fault as a consequence of block rotation associated with listric planes in the landslide-related active faults. At the edge of the main topographic scarp it is possible to see a $2 \mathrm{~m}$ displacement of the stromatolite bed. Total displacement in the ring fault in the main topographic scarp is accomplished through a system of parallel step faults. Underneath the stromatolites there is a $0.5-1.0 \mathrm{~m}$ thick tufa bed composed by $\mathrm{CaCO}_{3}$ precipitated around (or replacing) branches and twigs. The same tufa bed can be seen in many localities along the main fault scarp, just underneath the stromatolites. The scarp of a normal fault and roll over anticline are clearly exposed $\sim 200 \mathrm{~m} \mathrm{NE}$ of the picnic area. Total displacement on the outermost (with respect to the depocenter) fault scarp clearly increases toward the north. Just at the base of this "future main scarp" (Figure 15b) is a small graben formed by secondary normal faults with antithetic movement with relation to the main fault. We speculate that in the future the "present day main topographic scarp" will disappear as a consequence of mass movement of the sediments towards the depocenter and a new main scarp will form closer to the former shoreline. Thus, the whole stromatolite platform will be destroyed by the landslides. Close to the base of today's main topographic scarp there are large blocks ( $>1$ $\mathrm{m}$ long) randomly oriented, which are interpreted as a part 


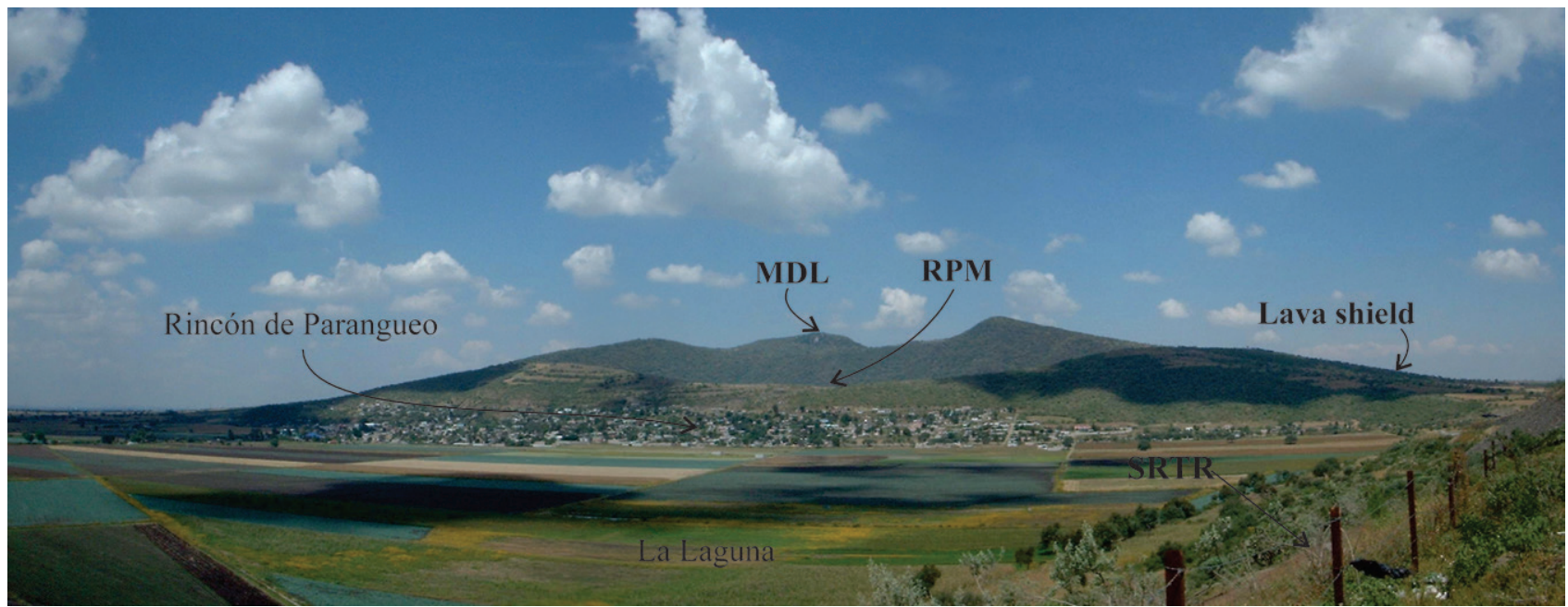

Figure 11. Panoramic view of the Parangueo volcanic complex as seen from the south from a vantage point located on the pyroclastic deposit of the Santa Rosa tuff ring. $\mathrm{MLD}=\mathrm{La}$ Mina lava dome, $\mathrm{RPM}=$ Rincón de Parangueo maar.

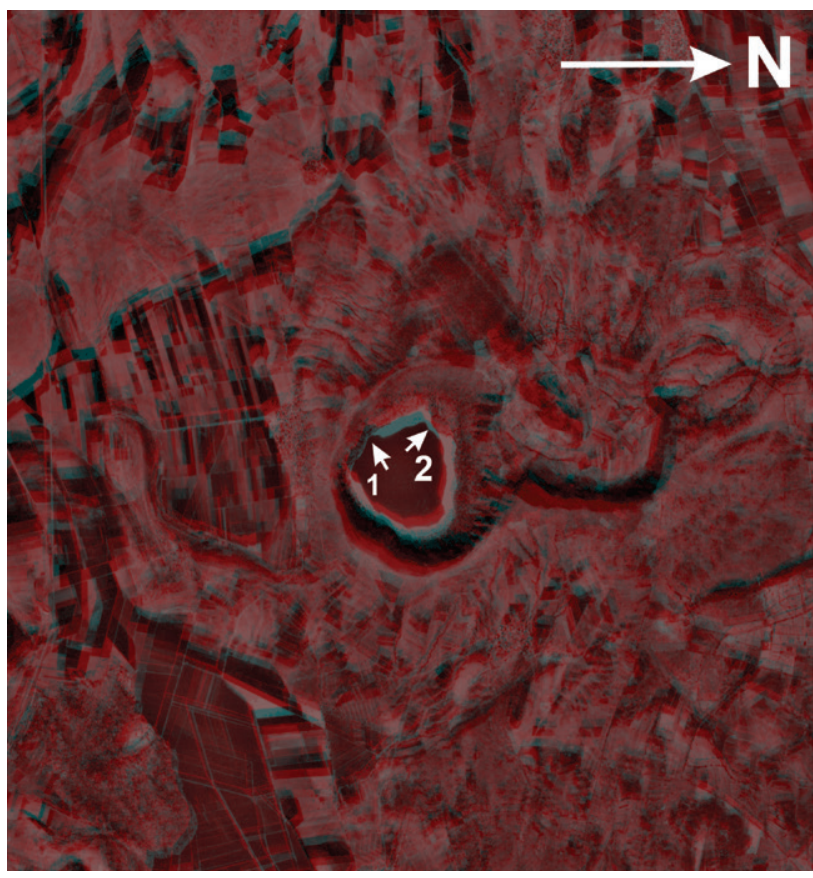

Figura 12. Epipolar image of the Parangueo volcanic complex obtained from a 1:75000 airphoto stereopair taken in March 1984. The use of anaglyphs is required to see the in 3D. Compare with geological map in Figure 11. The irregularly-shaped white ring roughly corresponds to the stromatolite biostrome prior to formation of landslides. White arrows 1 and 2 point out the vertical scarps depicted in figures $16 \mathrm{a}$ and $16 \mathrm{c}$, respectively. Note NW-trending lineaments located SW and NE of the maars; they are interpreted as normal faults.

of a landslide deposit (Figure 15b).

Near the shoreline of present day playa-lake are plenty of examples of a chaotic brecciated material weakly cemented by mud. Clast size in this brecciated material is considerably smaller than the landslide-related megabreccias. The finergrained breccia is interpreted as a product of the destruction

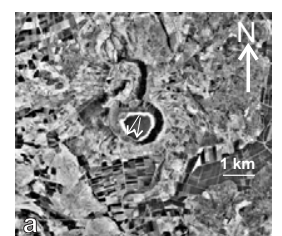

1984

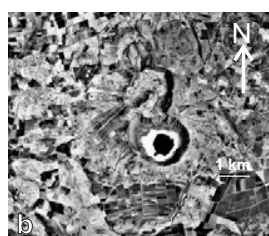

1999

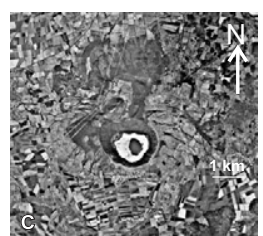

2003
Figure 13. Vertical air photos of the Rincón de Parangueo maar taken at three different dates. a) and b) were taken close to the dry season. They show that the lake inside the crater was shrinking. Escolero-Fuentes and Alcocer-Durand (2004) reported that by the end of the 2003 dry season it was completely dry. Thus, the water shown in c) was accumulated from rain water from the end of May to September of 2003. The lake basin was nearly dry in May 2010 (end of the dry season), while in October 2010 was very similar to $\mathrm{c}$. White arrows in a) point to the pre-desiccation embayments mentioned in the text.

of "desiccation columns" (mud blocks surrounded in all sides by deep desiccation cracks) during past dry seasons and cementation with new mud during subsequent wet seasons. In this area there are blocks that show pre-landslide convoluted bedding. We believe these are syn-sedimentary structures probably related to underwater turbidity currents triggered by earthquakes while the perennial lake still existed.

On the northwestern portion of the former lake $\left(20^{\circ}\right.$ $25.954^{\prime} \mathrm{N}, 101^{\circ} 15.211^{\prime} \mathrm{W}$ ) a stratified succession formed by coarse-grained, moderately well-indurated sandstone is exposed (Figure 16a). In a few places it is possible to see pebble trains where individual clasts are well rounded. Based on the interpretation of stereopairs, we infer the location of a fan delta associated with a small arroyo (Figure 14). Resting atop the sandstone there are fine grained, white, laminated lake sediments. A stromatolite bed exists at the top of the outcrop, just like in other parts of the main scarp. Near the base of the cliff the succession is covered by a talus deposit. At the top of the talus deposit a second 

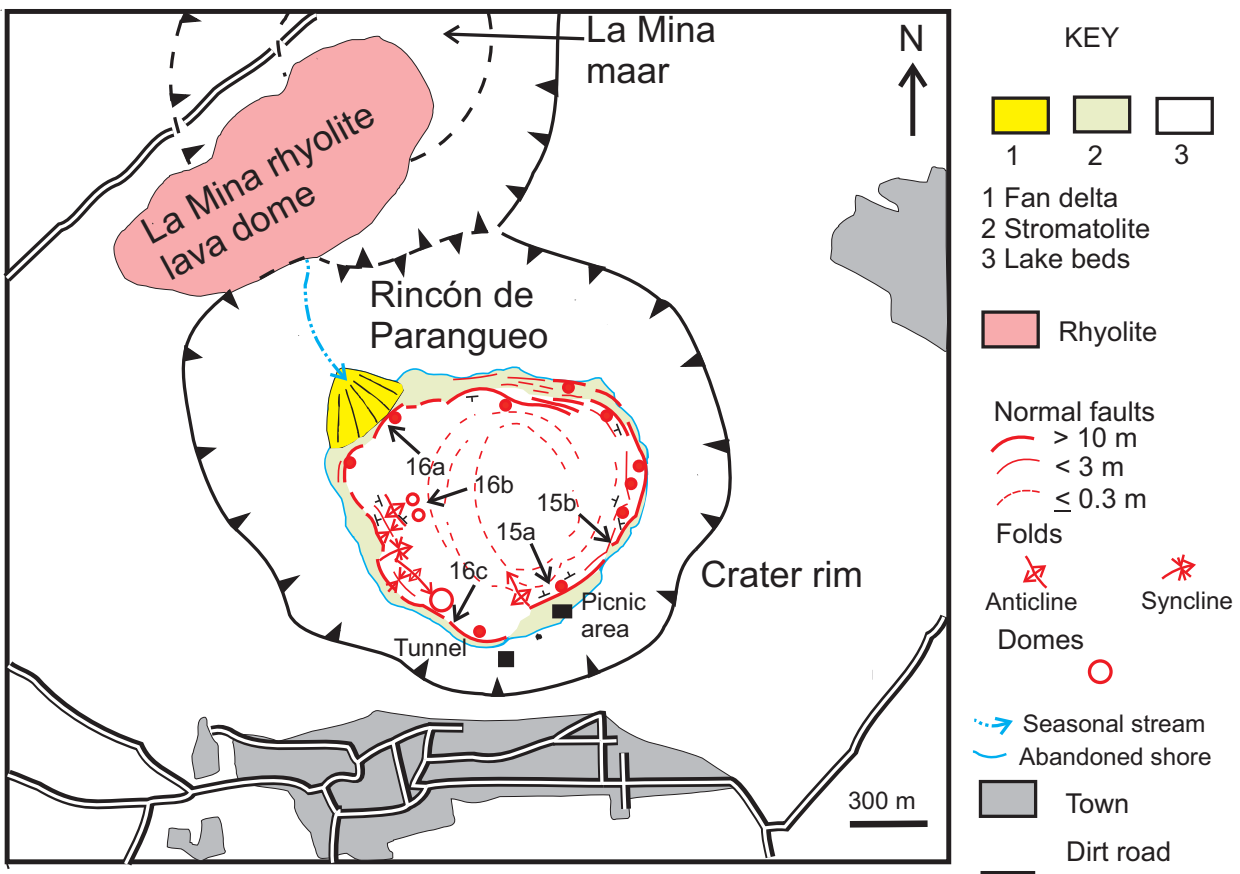

Figure 14. Structural sketch map of the bottom of the crater at Rincón de Parangueo and location of figures 15 and 16 (shown with arrows). Location of inferred faults or dissolution mini-scarps (?) in the "active" part of the lake at the deepest part of the crater, near present day depocenter, is highly uncertain.

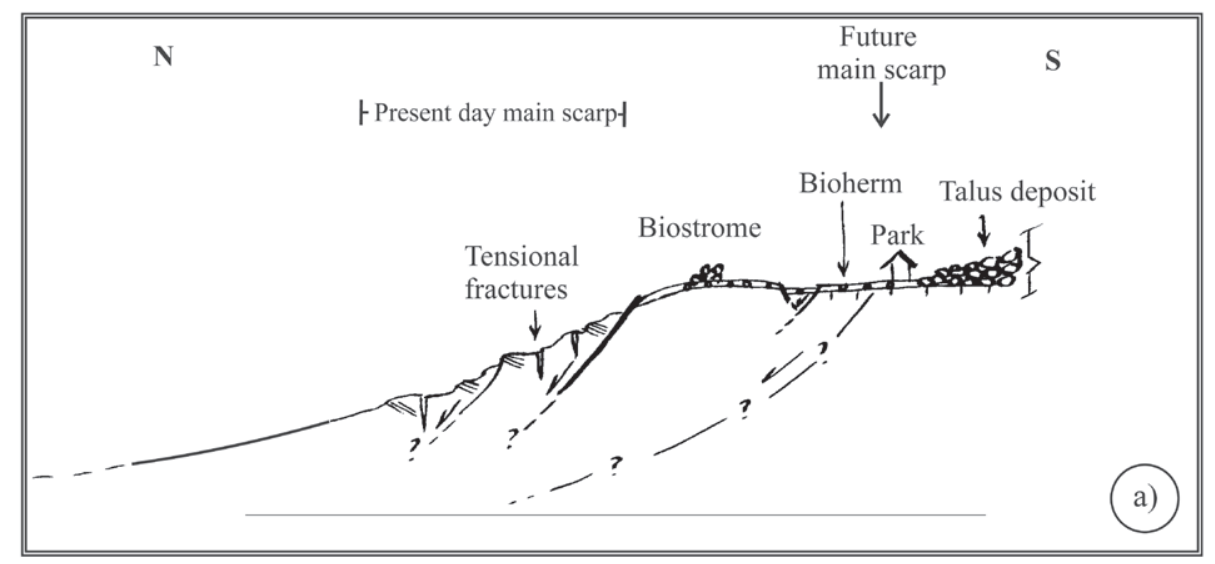

NW

SE

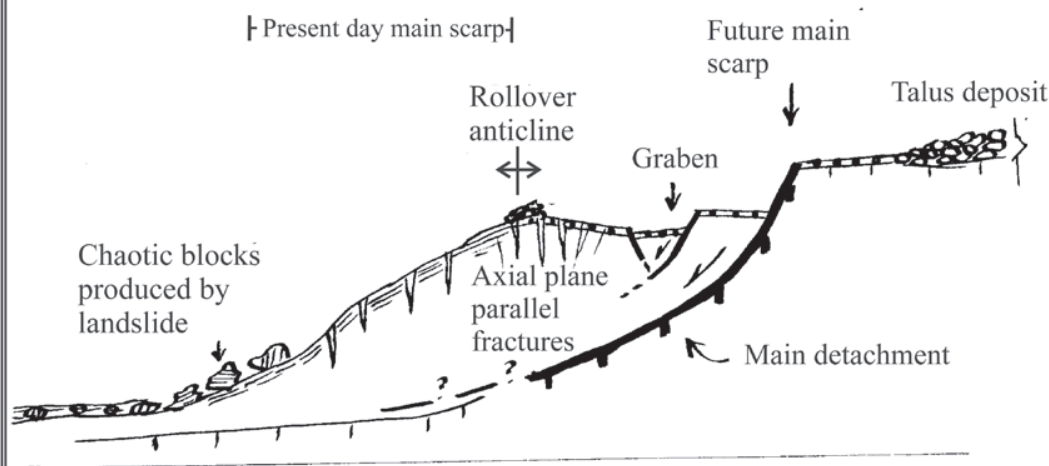

(b)

Figure 15 Schematic cross sections (no scale) displaying the main structural features discussed in the text. a) Near the picnic area inside the crater. b) Near the main fault scarp, about $200 \mathrm{~m} \mathrm{NE}$ of the picnic area. Both sections display the characteristic deformation style observed in the eastern part of the former lake bed. 
layer with stromatolites is exposed (Figure 16a), which was buried by the sand accumulated in the fan delta. These stromatolites commonly have a large fragment of wood or charcoal at their core. We interpret the lower stromatolites as evidence that the lake level had significant fluctuations in the past, which almost certainly were independent of man's activities (i.e. they pre-date drawdown in the aquifer). Near the base of the scarp is an exposed open fissure that suggests that the sediments are sliding towards the depocenter of the lake. Structural relations are complex in this area as there is evidence that the deposit may be formed, at least in part, by randomly oriented megablocks, product of a landslide. On the other hand, there is also a hint of a highly asymmetric anticline parallel to the topographic scarp, which has a gently tilted limb on the northern side and a steep limb in the southern side (Figure 16a). At the top of the scarp the sedimentary succession is a gently tilted surface formed by a stromatolite biostrome and well developed bioherms. Right at the edge of the platform, the tilt angle increases. We found an open fracture that suggests that in the near future the scarp wall will collapse as a topple (Figue 16a).

A strikingly different deformation style, as compared to the roll-over seen in the SE portion of the ring fault (Figure $15 \mathrm{~b})$, is exposed on the western part of the former lake. At

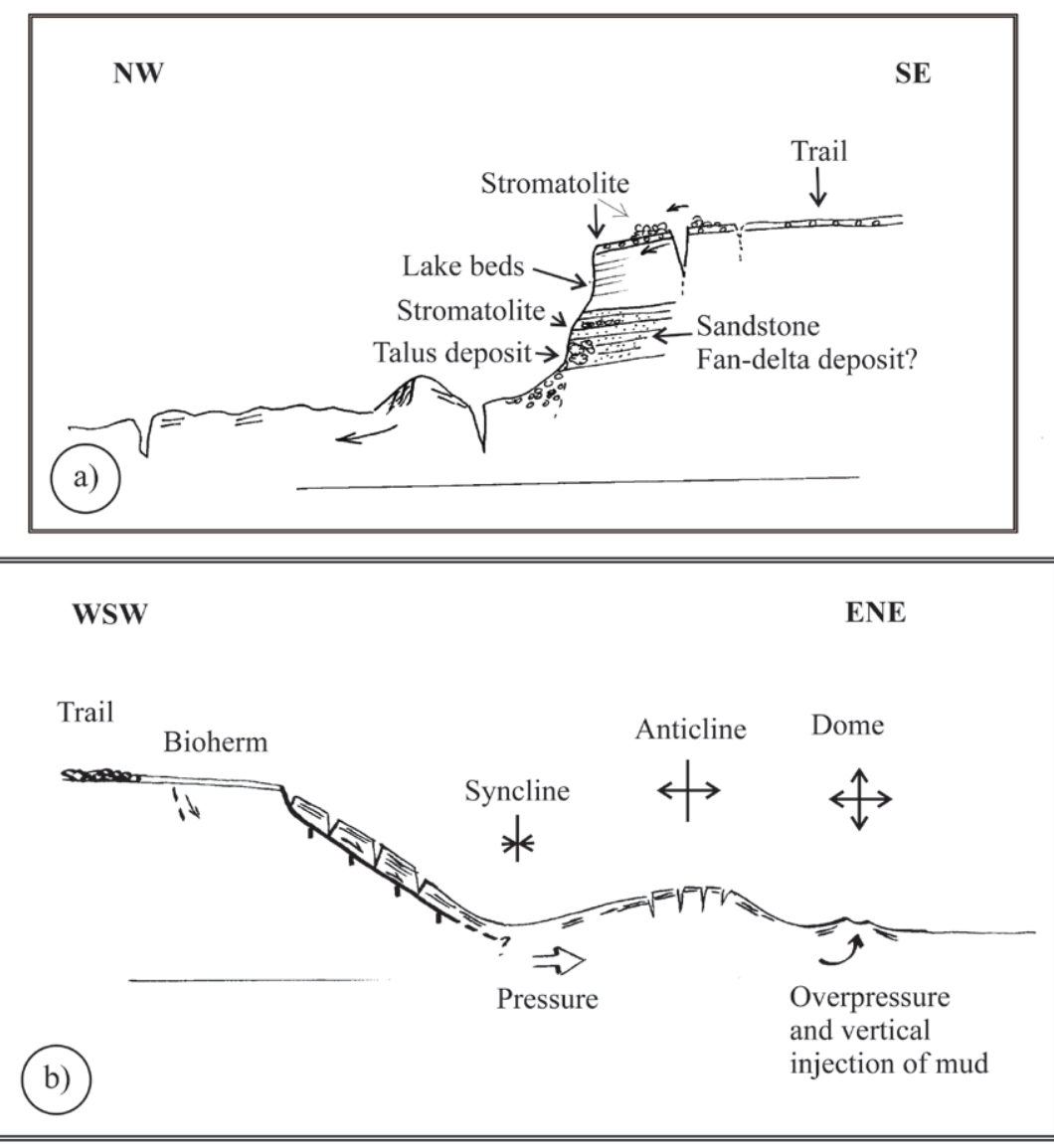

NE

SW

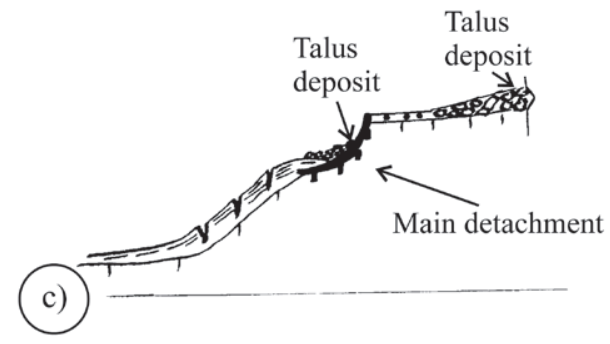

Figure 16. Schematic cross sections on the western part of the ring fault (see Figure 14 for locations of $a, b$, and c). No scale. Note the marked difference between figure $16 \mathrm{~b}$ and $15 \mathrm{~b}$. 
this site $\left(20^{\circ} 25.868^{\prime} \mathrm{N}, 101^{\circ} 15.216^{\prime} \mathrm{W}\right)$ it seems that large blocks are sliding along a flat surface tilted towards the depocenter (Figure 16b). Widely opened, curved tensional fractures are remarkable in this area. At the base of this structural feature there is no landslide deposit (i.e. randomly oriented megablocks). It appears as if the weight of the mass that is moving downward produces a syncline - anticline couple. Farther towards the ENE small domes, about $1 \mathrm{~m}$ high, are exposed. If the elongated hill that is shown as an anticline in Figure 16b is followed along the trace of the axial plane, it may be observed that the "anticline" is formed by a string of at least three domes (alternatively, the anticline may have an undulated axis). Tensional fractures are conspicuous at the top of the string of domes. We speculate that these structures, the "anticline" and domes, may have been formed by mud injection.

There are two distinct embayments or scallops in the SW portion of the lake in the 1984 airphotos used to prepare the epipolar image of Figure 12. These features already existed prior to the final desiccation of the lake (one of them is shown with the arrow labeled 2 in Figure 12 and 13a ). We believe these were produced by slope failure landslides similar to that depicted in Figure 16c. The absence of a landslide deposit (chaotic megabreccia) or syncline - anticline couple at the toe of the structure is consistent with presence of water and probably formation of a turbidity current that may have caused the convoluted bedding seen in some mud horizons in that area (?).

In the southernmost part of the former lake $\left(20^{\circ}\right.$ $25.585^{\prime} \mathrm{N}, 101^{\circ} 14.911^{\prime} \mathrm{W}$ ) the stromatolite platform has been completely destroyed by landslides. The area located immediately north is structurally complex. There are many large blocks randomly oriented. Likewise, folds with diverse orientations are also common. Some of the folds have their axial plane roughly perpendicular to the topographic scarp.

\section{Water composition and precipitation of trona}

Water composition (Table 1) of the lakes prior to the desiccation process is only known for La Alberca (EscoleroFuentes and Alcocer-Durand, 2004). However, La Alberca, according to the local people, was considerably less saline than Rincón de Parangueo. Presumably water at Hoya San Nicolás and Hoya Cíntora had even lower concentrations of salts than La Alberca and Rincón de Parangueo. It is worth noting that stromatolites commonly are extremophiles and that they are considerably better developed at Rincón de Parangueo, where water $\mathrm{pH}$ is $>10$ and salinity is larger than in the other craters (Table 2). Presence of some salts in San Nicolas' water is evidenced by very thin coatings of salts that occasionally can be seen covering the lake sediments in isolated patches during the dry season.

The presence in the lake sediments of trona $\left[\mathrm{Na}_{3}\left(\mathrm{CO}_{3}\right)\right.$ $\left.\left(\mathrm{HCO}_{3}\right) \cdot 2\left(\mathrm{H}_{2} \mathrm{O}\right)\right]$ and other sodium carbonates such as thermonatrite $\left[\mathrm{Na}_{2} \mathrm{CO}_{3} \cdot \mathrm{H}_{2} \mathrm{O}\right]$, natrite $\left[\mathrm{Na}_{2} \mathrm{CO}_{3}\right]$, and eitelite
$\left[\mathrm{Na}_{2} \mathrm{Mg}\left(\mathrm{CO}_{3}\right)_{2}\right]$, together with halite $[\mathrm{NaCl}]$ and silvite $[\mathrm{KCl}]$ suggests evaporite concentration from $\mathrm{Na}^{+}-\mathrm{HCO}_{3}^{-}$ type water produced by silicate hydrolysis of volcanic rock or volcaniclastic sediments. However, it has been noticed that not all the hydrological basins that meet these general requirements produce significant amounts $\mathrm{Na}-\mathrm{CO}_{3}$ minerals. An additional factor for trona precipitation is a high partial pressure of $\mathrm{CO}_{2}$. Earman et al. (2005) proposed that an input of magmatic $\mathrm{CO}_{2}$ can influence water chemistry such that trona would precipitate upon evaporation. An alternative source of "excess" $\mathrm{CO}_{2}$ in the Rincón de Parangueo system is related to organic decay or microbial activity. On the surface of the lake it is common to see isolated gas bubbles. Their origin is not yet clear to us, but in order to explain the presence of trona in the sediments, and following the proposal of Earman et al. (2005), we speculate that the gases may be $\mathrm{CO}_{2}$-rich and have a volcanic origin. However, in a recent visit (July 2010), near the shore of the playa-lake we noticed the presence of floating rafts of algae (?) or bacteria surrounded by light brown foam, which suggests that some (or all?) the gas may be of organic origin. On the other hand, gas bubbles form small craters in thick evaporite crusts during the dry season (Figure 17) when algae mats are not obvious.

\section{Discussion}

Subsidence is a widespread phenomenon at El Bajío. The best documented examples of subsidence-related faults occur at Celaya and Salamanca, where fault nucleation and movement was detected several decades ago. Historical records show that accumulated displacement, length and number of faults has steadily increased with time in both cities. General orientation of subsidence faults appears to follow the regional trends of tectonic faults in the region: NNW at Celaya, parallel to the San Miguel Allende fault and

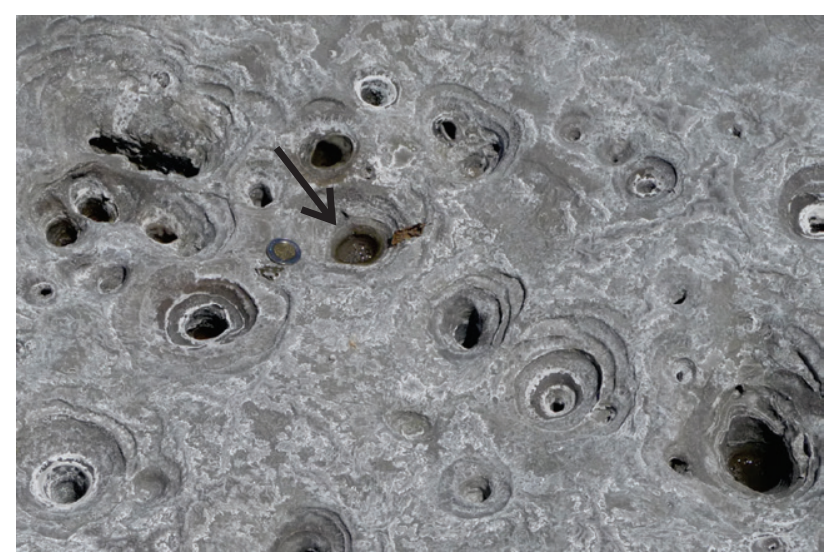

Figure 17. Thick crust of evaporite formed during the dry season of 2009 shows small craters formed by gas bubbles (arrow). The craters suggest that gas was continuously expelled thru conduits that acted during time periods of days or weeks. Note coin near the arrow as a scale. 
ENE at Salamanca parallel to the Chapala-Tula fault system. We believe that the orientations of the subsidence-related faults are determined by the tectonic grain imprinted in the bedrock buried under thick sequences of fluvial and lake sediments and pyroclastic deposits. Likewise, the ultimate location of the faults in the surface may be determined by local relief in the buried bedrock. Subsidence faults are difficult to locate in rural areas as work associated with intensive agriculture tends to mask the growing scarps. However, faults may still be detected where they cut across the paved roads or irrigation channels.

We consider maar desiccation in the Valle de Santiago area as a consequence of drawdown in the Valle de Santiago - Salamanca aquifer (Aranda-Gómez et al., 2009). Therefore, subsidence at the bottom of the crater could be, in part, associated with this phenomenon as significant compaction of the lake beds probably occurred. A comparison between the mean subsidence velocity in the Salamanca fault $(6 \mathrm{~cm} /$ year $)$ and the collapse structure inside the crater $(50 \mathrm{~cm} /$ year; assuming that the at least 10 $\mathrm{m}$ high topographic scarp was formed in the past 20 years) suggests that an additional process may be operating in the crater. Presence of a significant amount of the water-soluble salts halite, sylvite, trona, and other $\mathrm{Na}$ carbonates was established by us using XRD. In a simple test to estimate the amount of soluble minerals in a small lake sediment sample, collected near the depocenter, $33 \mathrm{wt} \%$ of the previously dried sample was easily dissolved in distilled water at room temperature. Thus, the remarkable collapse features observed at the bottom of the crater may have been formed in a similar way to the sinkholes studied by Closson (2004) and Closson et al. (2005) around the Dead Sea. Closson (op . cit) first proposed a model where the flow of unsaturated groundwater dissolved concealed evaporite layers, which caused the formation of underground cavities that later collapsed, producing sinkholes on the surface. Although there are no reports of formation of sinkholes at Rincón de Parangueo, we envision a gradual removal of the soluble salts, and an increase of the height difference between the depocenter of lake and its shore creating the potential for continuous slow movement landslides. The Rincón de Parangueo maar is a partly closed system. Rainwater that falls inside the closed basin of crater is now feeding an ephemeral playa lake. Freshwater rain can dissolve the soluble salts in the lake sediments. Part of the newly formed brine infiltrates the ground and the rest is lost through evaporation with the consequent re-precipitation of part of the dissolved salts. We hypothesize that underground water flow is now moving solutes into the regional aquifer. Residents of the area have noticed an increase in the salinity of the water in their wells in recent years.

Landslides observed in the western and southwestern part of the collapse ring were probably triggered by support removal at the base of the ring fault scarp as the bottom of the lake subsided. The 1984 airphoto (Figure 13) shows two scallops (landslide scars?) formed before the total desiccation of the lake occurred. Thus, some of the active structures observed in the crater floor may have started before total desiccation of the lake.

\section{Acknowledgments}

Financial support for our work in Valle de Santiago has been provided by grants PAPIIT IN109410-3 and CONACyT 129550, both to J. Aranda.

\section{References}

Allaby, A., Allaby, M., 1999, Microbialite, 1999, A Dictionary of Earth Sciences: available at http://w.w.w.encyclopedia.com, consulted October 12, 2010.

Aranda-Gómez, J.J., Carrasco-Núñez, G., Levresse, G., Pacheco-Martínez, J., Ramos-Leal, J.A., Vega-González, M., Chacón-Baca, E., ChávezCabello, G., 2010a, The maar volcanoes of the Valle de Santiago region (Guanajuato, México): a record of water - molten rock interaction, in Water Rock Interaction: Guanajuato, Gto., México, International Association of GeoChemistry, 1-25.

Aranda-Gómez, J.J., Chacón-Baca, E., Charles-Polo, M., Solorio-Munguía, J.G., Vega-González, M., Moreno-Arredondo, A., Origel-Gutiérrez, G., 2009, Collapse structures at the bottom of a recently desiccated maar lake: Rincón de Parangueo maar, Valle de Santiago, México, in IAVCEI $3^{\text {rd }}$ International Maar Conference: Malargüe, Argentina, Asociación Geológica Argentina Publicaciones Especiales, 12, 3-4.

Aranda-Gómez, J.J., Housh, T.B., Luhr, J.F., Carrasco-Nuñez, G., 2002, Geología de la región de Valle de Santiago (Guanajuato): Informe preliminar: GEOS, 22, 392.

Aranda-Gómez, J.J., Levresse, G., Pacheco-Martínez, J., Ramos-Leal, J.A., Carrasco-Núñez, G., Chacón-Baca, E., González-Naranjo, G., Chávez-Cabello, G., Vega-González, M., Origel-Gutiérrez, G., Noyola-Medrano, C., 2010b, Active subsidence at the bottom of a recently desiccated crater-lake and its environmental impact: Rincón de Parangueo, Guanajuato, México: Field trip guidebook, in Eighth International Symposium on Land Subsidence: Querétaro, Qro., México, International Association of Hydrogeological Sciences, $1-48$.

Aranda-Gómez, J.J., Luhr, J.F., Pier, J.G., 1992, The La Breña-El Jagüey maar complex, Durango, México: I Geological evolution: Bulletin of Volcanology, 54, 393-404.

Armienta, M.A., Vilaclara, G., De la Cruz-Reyna, S., Ramos, S., Ceniceros, N., Cruz, O., Aguayo, A., Arcega-Cabrera, F., 2008, Water chemistry of lakes related to active and inactive Mexican volcanoes: Journal of Volcanology and Geothermal Research, 178, 249-258.

Arzate, J.A., Aguirre-Díaz, G.J., Arroyo, M., 1999, Mediciones geofísicas aplicadas al estudio de la falla Tarimoro-San Miguel Allende (SMA); una posible discontinuidad mayor en el basamento: GEOS, 19, 237.

Ávila-Olivera, J.A., 2009, Evolución de los procesos de subsidencia-creepfalla, casos: Morelia, Mich. y Celaya, Gto.: México, D.F., Posgrado en Ciencias de la Tierra, Universidad Nacional Autónoma de México, tesis doctoral, $232 \mathrm{p}$.

Avila-Olivera, J.A., Garduño-Monroy, V.H., 2008, A GPR study of subsidence-creep-fault processes in Morelia, Michoacán, México: Engineering Geology, 100, 69-81

Ávila-Olivera, J.A., Farina, P., Garduño-Monroy, V.H., 2010, Land subsidence monitored by satellite interferometry in Mexican cities, in Land Subsidence, Associated Hazards and the Role of Natural Resources Development; Proceedings of EISOLS 2010: Querétaro, Qro., México, International Association of Hydrogeological Sciences Publication, 339, 316-318. 
Blatter, D.L., Hammersley, L., 2010, Impact of the Orozco Fracture Zone on the central Mexican Volcanic Belt: Journal of Volcanology and Geothermal Research, 197, 67-84.

Borja-Ortíz, R.I., Rodríguez, C.R., 2004, Aquifer vulnerability changes due to faults and riverbeds in Salamanca, Guanajuato, Mexico: Geofísica Internacional, 43, 623-628.

Brown, R.J., Branney, M.J., Maher, C., Dávila-Harris, P., 2010, Origin of accretionary lapilli within ground-hugging density currents: evidence from pyroclastic couplets on Tenerife: Geological Society of America Bulletin, 122, 305-320.

Cas, R.A.F., Wright, J.V., 1988, Volcanic successions; modern and ancient: London, United Kingdom, Unwin Hyman, 528 p.

Closson, D., 2004, Structural control of sinkholes and subsidence hazards along the Jordanian Dead Sea coast: Environmental Geology, 47, 290-301.

Closson, D., Karaki, N.A., Klinger, Y., Hussein, M.J., 2005, Subsidence and sinkhole hazard assessment in the southern Dead Sea area, Jordan: Pure and Applied Geophysics, 162, 221-248.

Connor, C.B., 1990, Cinder cone clustering in the TransMexican Volcanic Belt: Implications for structural and petrological models: Journal of Geophysical Research, 95, 19395-19405.

Demant, A., 1978, Características del Eje Neovolcánico Tansmexicano: Instituto de Geología, Universidad Nacional Autónoma de México, Revista, 2, 172-187.

Díaz-Salmerón, J.E., Hernández-Madrigal, V.M., Garduño-Monroy, V.H., Giordano, N., Cabral-Cano, E., Díaz-Molina, O., CamargoValencia, V.A., 2010, Geometry and monitoring with GPS of the subsidence-creep-fault processes in Celaya, Guanajuato, Mexico, in Abstracts of the Eighth International Symposium on Land Subsidence 2010: Querétaro, Qro., México, International Association of Hydrogeological Sciences, 29.

Earman, S., Phillips, F.M., McPherson, B.J., 2005, The role of "excess" $\mathrm{CO}_{2}$ in the formation of trona deposits: Applied Geochemistry, 20, 2217-2232.

Escolero-Fuentes, O.A., Alcocer-Durand, J., 2004, Desecación de los lagos cráter del Valle de Santiago, Guanajuato, in Jiménez, B., Marín, L., Morán, D., Escolero, O., Alcocer, J. (eds.), El agua en México vista desde la Academia: México, D.F., México, Academia Mexicana de Ciencias, 99-116.

Giordano, N., Díaz-Molina, O., Cabral-Cano, E., Garduño-Monroy, V.H., Hernández-Madrigal, V.M., Camargo-Valencia, A., 2010a, The application of ground penetrating radar in the study of subsidence-creep induced faults in Celaya, in Abstracts of the Eighth International Symposium on Land Subsidence 2010, Querétaro, Qro., México, International Association of Hydrogeological Sciences, 8.

Giordano, N., Díaz-Salmerón, J.E., Hernández-Madrigal, V.M., GarduñoMonroy, V.H., Camargo-Valencia, A., 2010b, Subsidence in Celaya, Guanajuato: Morphologic evolution and relations with aquifer's dynamic, in Abstracts of the Eighth International Symposium on Land Subsidence 2010, Querétaro, Qro., México, International Association of Hydrogeological Sciences, 78-79.

Hasenaka, T., 1992a, Contrasting volcanism in the Michoacán-Guanajuato volcanic field, central Mexico: Shield volcanoes vs. cinder cones, in Aoki, K.I. (ed.), Subduction volcanism and tectonics of western Mexican volcanic belt: Sendai, Japan, The Faculty of Science, Tohoku University, 142-162.

Hasenaka, T., 1992b, Size, distribution and magma output rate for shield volcanoes of the Michoacan-Guanajuato volcanic field, central Mexico, in Aoki, K.I. (ed.), Subduction volcanism and tectonics of western Mexican Volcanic Belt, Sendai, Japan, The Faculty of Science, Tohoku University, 115-141.

Hasenaka, T., Carmichael, I.S.E., 1985, The cinder cones of the MichoacanGuanajuato, central Mexico: their age, volume, and distribution, and magma discharge rate: Journal of Volcanology and Geothermal Research, 25, 104-124.

Highland, L., 2004, Landslides types and processes, U.S. Geological Survey Fact sheet 2004-3072: 1-4, available at http://pbs.usgs.gov/ fs/2004/3072/, consulted october 102010.
Huízar-Álvarez, R., Mitre-Salazar, L.M., Marín-Córdova, S., TrujilloCandelaria, J., Martínez-Reyes, J., 2010, Subsidence in Celaya, Guanajuato, central Mexico: implications of groundwater extraction and neotectonic regime: Geofísica Internacional, 50, 255-270.

Johnson, C.A., Harrison, C.G.A., 1990, Neotectonics in central Mexico: Physics of the Earth and Planetary Interiors, 64, 187-210.

Kienel, U., Bowen, S.W., Byrne, R., Park, J., Böhnel, H., Dulski, P., Luhr, J.F., Siebert, L., Haug, G.H., Negendank, J.F.W., 2009, First lacustrine varve chronologies from Mexico: impact of droughts, ENSO and human activity since AD 1840 as recorded in maar sediments from Valle de Santiago: Journal of Paleolimnology, 42, 587-609.

Leake, S.A., 2010, Land subsidence from ground-water pumping: available at http://geochange.er.usgs.gov/sw/changes/anthropogenic/subside/, consulted October 6, 2010.

Lorenz, V., 1986, On the growth of maars and diatremes and its relevance to the formation of tuff rings: Bulletin of Volcanology, 48, 265-274.

Lorenz, V., 2003, Maar-diatreme volcanoes, their formation, and their setting in hard-rock or soft-rock environments: Geolines, 15, 72-83.

Luhr, J.F., Kimberly, P., Siebert, L., Aranda-Gómez, J.J., Housh, T.B., Kysar, G., 2006, México's Quaternary volcanic rocks: Insights from the MEXPET petrological and geochemical database: Geological Society of America Special Paper, 402, 1-44.

Martínez-Reyes, J., Nieto-Samaniego, A.F., 1992, Efectos geológicos de la tectónica reciente en la parte central de México: Instituto de Goelogía, Universidad Nacional Autónoma de México, Revista, 9, 33-50.

Mejía, J.A., Ramírez, R., Berlin, J., 2001, Hydrodynamic and pollution of the urban aquifer system of Salamanca, Gto. The Salamanca case 1, in Proceedings I International Workshop on investigation, management and remediation of contaminated aquifers: Alicante, Spain, 335-345, available at http://aguas.igme.es/igme/publica/ pdflib15/031.pdf, consulted september 292010.

Mejía, J.A., Rodríguez, R., Armienta, A., Mata, E., Fiorucci, A., 2007, Aquifer vulnerability zoning, an indicator of atmospheric pollutants input? Vanadium in the Salamanca aquifer, Mexico: Water, Air, \& Soil Pollution, 185, 95-100.

Mejía, J.A., Sandoval, R., 2004, Uso del agua subterránea en la región acuífera Irapuato - Valle de Santiago (México) y su impacto sobre el sistema hidrogeológico: Boletín Geológico y Minero, 115, 311-318.

Molina-Garza, R.S., Urrutia-Fucugauchi, J., 1993, Deep crustal structure of central Mexico derived from interpretation of Bouger gravity anomaly: Journal of Geodynamics, 17, 181-201.

Murphy, G. P., 1986, The chronology, pyroclastic stratigraphy, and petrology of the Valle de Santiago maar field, central Mexico: Berkeley, CA, U.S.A., University of California, tesis de maestría, $55 \mathrm{p}$.

Nakamura, K., 1977, Volcanoes as possible indicators of tectonic stress orientation- principle and proposal: Journal of Volcanology and Geothermal Research, 2, 1-16.

Ordóñez, E., 1900, Les volcans du Valle de Santiago: México, Memorias de la Sociedad Científica Antonio Alzate, XIV, 299-326.

Orozco, F., Madinaveitia, A., 1941, Estudio químico de los lagos alcalinos: Anales del Instituto de Biología, Universidad Nacional Autónoma de México, 12, 429-438.

Pacheco-Martínez, J., 2007, Modelo de subsidencia del Valle de Querétaro y predicción de agrietamientos superficiales: Querétaro, México, Posgrado en Ciencias de la Tierra, Universidad Nacional Autónoma de México, tesis doctoral, $225 \mathrm{p}$.

Pardo, M., Suárez, G., 1995, Shape of the subducted Rivera and Cocos plates in southern Mexico: seismic and tectonic implications: Journal of Geophysical Research, 100, 12357-12373.

PEMEX, 2010, Pemex Gas y Petroquímica básica, available at http://www. gas.pemex.com/pgpbenglish/about $\% 20$ pemex $\% 20$ gas, consulted october 52010.

Rincón, N., 2005, Estratigrafía del cráter de explosión Hoya La Alberca: Ciudad Madero, Tamaulipas, México, Instituto Tecnológico de Ciudad Madero, tesis ingeniero geólogo, 78 p. 
Rodríguez, R., 2004, The role of urban areas in aquifer vulnerability assessments: The Salamanca, Mexico, case: Geofísica Internacional, 43, 583-589.

Soler-Arrechalde, A.M., Urrutia-Fucugauchi, J., 1993, The QuerétaroTaxco fracture system: a major NW-SE fault and crustal discontinuity in Central Mexico: EOS, 74, 577.

Suter, M., Quintero-Legorreta, O., López-Martínez, M., Aguirre-Díaz, G.J., Farrar, E., 1995, The Acambay graben: Active intraarc extension in the trans-Mexican volcanic belt, Mexico: Tectonics, 14, 1245-1262.

Trujillo-Candelaria, J.A., 1985, Subsidencia de terrenos en la ciudad de Celaya, Gto., in Reunión sobre Asentamientos Regionales: México, D.F., México, Sociedad Mexicana de Mecánica de Suelos y Asociación Geohidrológica Mexicana, 1-2.

Turati, M., 2008, Las 7 plagas que azotaron Salamanca, available at http://marcelaturati.wordpress.com/2008/11/03/las-7-plagas-queazotaron-salamanca/, consulted october 12010.
Urrutia-Fucugauchi, J., Soler-Arrechalde, A.M., Flores-Ruiz, J.M., 1995, Tectonics and volcanism in central Mexico -influence of preNeogene tectonics in the plate subduction-magmatic arc system: Geological Society of America Abstracts with programs, 27, 189.

Manuscript received: October 18, 2010.

Corrected manuscript received: August 10, 2011.

Manuscript accepted: August 18, 2011. 